A】l】0己 6อコ95】

NATL INST OF STANDARDS \& TECH R.I.C.

In|.

A11102623951

Kusuda, Tamaml/Savings in electrlc cooll

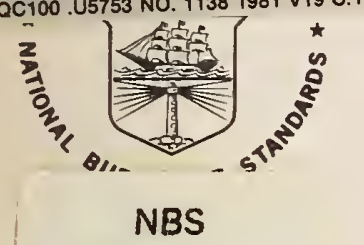

NBS TECHNICAL NOTE 1138

PUBLICATIONS

U.S. DEPARTMENT OF COMMERCE/National Bureau of Standards

\title{
Savings in Electric Cooling Energy By the Use of a Whole-House Fan
}

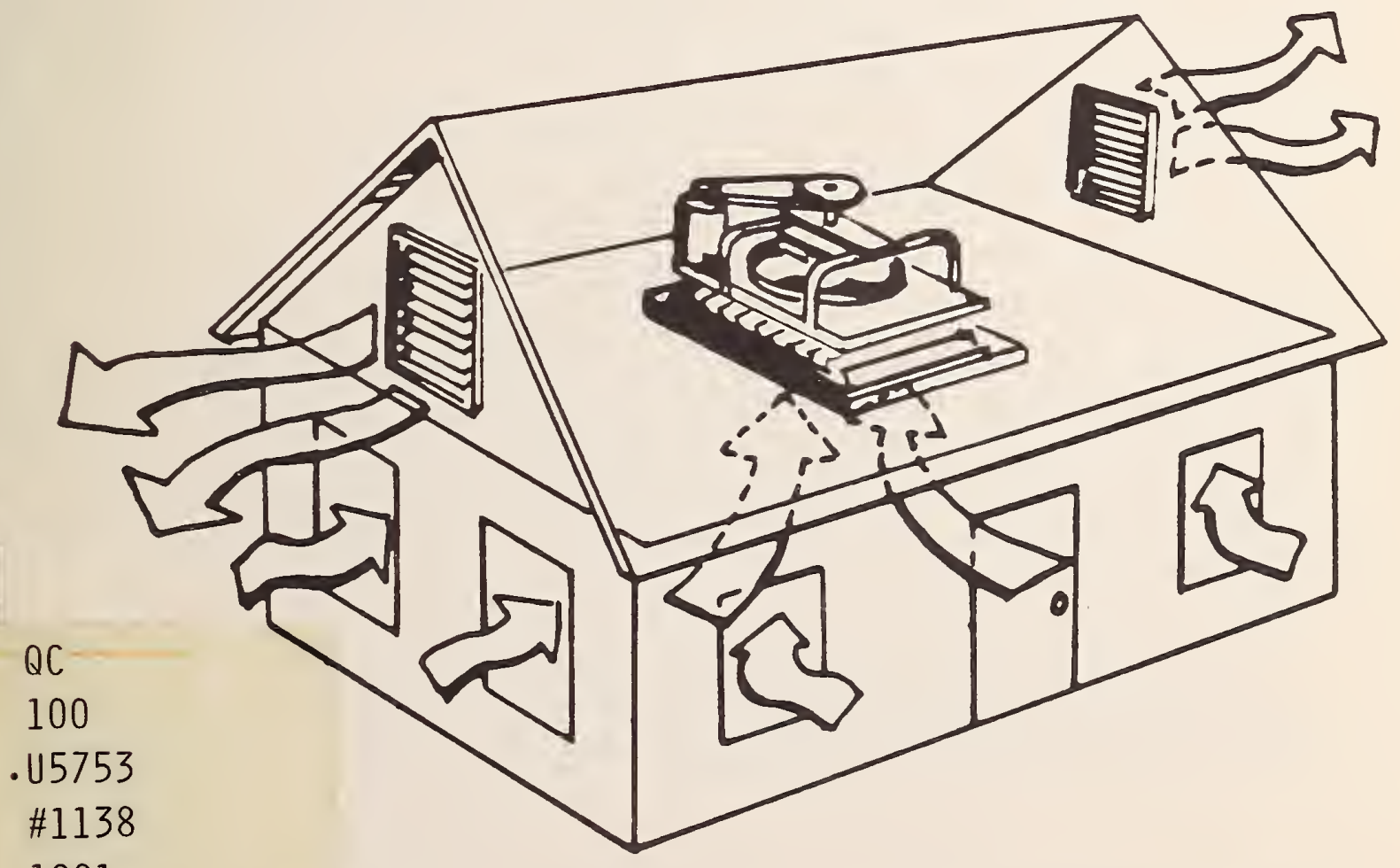

1981

C.2 


\section{NATIONAL BUREAU OF STANDARDS}

The National Bureau of Standards' was established by an act of Congress on March 3, 1901. The Bureau's overall goal is to strengthen and advance the Nation's science and technology and facilitate their effective application for public benefit. To this end, the Bureau conducts research and provides: (1) a basis for the Nation's physical measurement system, (2) scientific and technological services for industry and government, (3) a technical basis for equity in trade, and (4) technical services to promote public safety. The Bureau's technical work is performed by the National Measurement Laboratory, the National Engineering Laboratory, and the Institute for Computer Sciences and Technology.

THE NATIONAL MEASUREMENT LABORATORY provides the national system of physical and chemical and materials measurement; coordinates the system with measurement systems of other nations and furnishes essential services leading to accurate and uniform physical and chemical measurement throughout the Nation's scientific community, industry, and commerce; conducts materials research leading to improved methods of measurement, standards, and data on the properties of materials needed by industry, commerce, educational institutions, and Government; provides advisory and research services to other Government agencies; develops, produces, and distributes Standard Reference Materials; and provides calibration services. The Laboratory consists of the following centers:

Absolute Physical Quantities ${ }^{2}$ - Radiation Research - Thermodynamics and Molecular Science - Analytical Chemistry - Materials Science.

THE NATIONAL ENGINEERING LABORATORY provides technology and technical services to the public and private sectors to address national needs and to solve national problems; conducts research in engineering and applied science in support of these efforts; builds and maintains competence in the necessary disciplines required to carry out this research and technical service; develops engineering data and measurement capabilities; provides engineering measurement traceability services; develops test methods and proposes engineering standards and code changes; develops and proposes new engineering practices; and develops and improves mechanisms to transfer results of its research to the ultimate user. The Laboratory consists of the following centers:

Applied Mathematics - Electronics and Electrical Engineering 2 - Mechanical

Engineering and Process Technology $y^{2}$ - Building Technology - Fire Research -

Consumer Product Technology — Field Methods.

THE INSTITUTE FOR COMPUTER SCIENCES AND TECHNOLOGY conducts research and provides scientific and technical services to aid Federal agencies in the selection, acquisition, application, and use of computer technology to improve effectiveness and economy in Government operations in accordance with Public Law 89-306 (40 U.S.C. 759), relevant Executive Orders, and other directives; carries out this mission by managing the Federal Information Processing Standards Program, developing Federal ADP standards guidelines, and managing Federal participation in ADP voluntary standardization activities; provides scientific and technological advisory services and assistance to Federal agencies; and provides the technical foundation for computer-related policies of the Federal Government. The Institute consists of the following centers:

Programming Science and Technology-Computer Systems Engineering.

'Headquarters and Laboratories at Gaithersburg, MD, unless otherwise noted; mailing address Washington, DC 20234.

${ }^{2}$ Some divisions within the center are located at Boulder, CO 80303. 


\section{Savings in Electric Cooling Energy By the Use of a Whole-House Fan}

T. Kusuda

J. W. Bean

Center for Building Technology

National Engineering Laboratory

National Bureau of Standards

Washington, D C 20234

This report was prepared under NBS STRS project 7421216 and

NBS/CBT DACTAP project 7421219

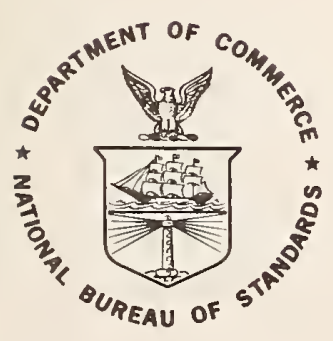

U.S. DEPARTMENT OF COMMERCE, Malcolm Baldrige, Secretary NATIONAL BUREAU OF STANDARDS, Ernest Ambler, Director 


\section{National Bureau of Standards Technical Note 1138}

Nat. Bur. Stand. (U.S.), Tech. Note 1138, 39 pages (May 1981)

CODEN: NBTNAE

U.S. GOVERNMENT PRINTING OFFICE WASHINGTON: 1981

For sale by the aperintendent of Documents, U.S. Government Printing Office, Washington, D.C. 20402 Price $\$ 2.75$

(Add 25 percent for other than U.S. mailing) 
Savings in Electric Cooling Energy by

the Use of a Whole-House Fan

T. Kusuda and J. W. Bean

\begin{abstract}
Hour-by-hour cooling performances of a typical ranch house, with and without the use of a whole-house fan, were compared for the climate conditions throughout the contiguous United States. The comparative analyses were made by the use of NBSWHF, a modified version of NBSLD, to simulate the complex thermal coupling of whole-house-fan ventilated attic space. The calculations were performed for two operational modes: a cyclic fan mode and a stepwise continuous mode. The calculation predicted a large cooling energy savings as compared to the house without the use of the whole-house fan, without significant deterioration of indoor thermal comfort.

Key Words: building thermal performance; energy calculation; energy conservation; thermal comfort; whole-house ventilation.
\end{abstract}


The work reported in this Technical Note was sponsored by the National Bureau of Standards. Part of the motivation for this analytical study was the extremely beneficial results revealed in a limited field study of the whole-house-fan approach to cooling. That field study was a minor part of a DOE/NBS project sponsored by the U.S. Department of Energy. The authors gratefully acknowledge DOE's interest and support of that project, entitled Attic Ventilation Criteria, which was conducted in Houston, Texas in 1977-78. 
CONTENTS

ABSTRACT . . . . . . . . . . . . . . . . 1 . 1 . .

ACKNOWLEDGMENT . . . . . . . . . . . . . . . . iv

1. INTRODUCTION . . . . . . . . . . . . . . . 1

2. COMPUTER SIMULATION . . . . . . . . . . . . . 2

3. TEST HOUSES

2

4. CALCULATED COOLING ENERGY CONSUMPTION . . . . . . . 3

5. CONCLUSIONS . . . . . . . . . . . . . . . 7

6. REFERENCES . . . . . . . . . . . . . . . 7

$\mathrm{V}$ 


\section{INTRODUCTION}

During the summer of 1977, NBS engineers conducted extensive tests on attic ventilation in three unoccupied test houses in Houston, Texas ${ }^{1}$. Although this NBS test concluded that the attic fan was ineffective for savings in cooling energy consumption, a limited study conducted on the attic wholehouse fan proved to be extremely beneficial.

While an attic fan is usually installed at the gable and draws the outdoor air through gable and soffit ventilation openings, the attic whole-house fan is mounted at the ceiling, and draws outside air through windows and exhausts it through the attic space. The fan would be turned on whenever the outdoor temperature is low enough to provide natural cooling. Since an average whole-house fan would require 400 to 500 watts of electrical energy as contrasted to the 2500 to 3000 required for central air conditioning, it is easy to see that significant electrical energy savings are possible by substituting the use of a whole-house fan for a central air conditioner.

Most of the whole-house fans are designed to ventilate a house at $1 / 2$ to 1 air change per minute. If the house temperature is to be maintained at a reasonably comfortable condition, the use of a whole-house fan could be substituted for that of an air conditioner whenever the outdoor temperature is less than about $82^{\circ} \mathrm{F}$.

Table 1 shows the number of hours during the year when the outdoor temperature is less than $82^{\circ}$ but higher than $65^{\circ}$ for ten different cities in the United States. The lower limit of $65^{\circ}$ was chosen because it would be unlikely that either natural or whole-house ventilation would be used when the outdoor temperature was that low. Natural ventilation simply by opening windows (but without the fan running) may be sufficient below $72^{\circ} \mathrm{F}$. The number of hours shown in Table 1 that occur when the outdoor temperature falls within the $72-82^{\circ}$ temperature bin, therefore, represents a potential number of hours when the whole-house fan can be utilized.

The actual number of hours when the whole-house fan is used, however, depends strongly upon the interaction between the building heat transfer and storage characteristics with respect to the cooling potential of the outdoor air. The actual electrical energy savings obtained by the use of the whole-house fan is also dependent upon the manner in which it is operated. The purpose of this study is to evaluate the effectiveness of whole-house ventilation by simulating the detailed building heat transfer process with respect to the mode of operation of a whole-house fan.

The whole-house fan may be activated as soon as the outdoor temperature falls below a set point, and left running continuously not only to maintain the comfort condition but also even to undercool the house. The undercooling is done intentionally to store the coolness to counter the hot daytime condition that follows. Unless carefully monitored, however, this mode of operation may end up wasting a large amount of fan energy. 
The wasting of the fan energy may be reduced by reducing the fan speed in accordance with a predetermined control strategy. The fan also may be cycled by an indoor thermostat. This paper addresses several selected modes of whole-house-fan operation. Additional work is needed to identify the energy savings potential of other possible modes of operation.

\section{COMPUTER SIMULATION}

The National Bureau of Standards Heating and Cooling Load Determination Program, NBSLD, is a comprehensive hourly simulation computer program based on detailed radiant exchange heat balance among the interior surfaces of the building, as well as the transient heat conduction through the various components of the building envelope. Details of this program are given in reference 2. NBSLD was first modified to simulate the detailed heat transfer and thermal storage process of whole-house-fan operation. The modified NBSLD, called NBSWHF, was then validated by comparing its results with the measured results of the Houston test house. The modification is in the attic temperature and heat transfer algorithm to account for precise radiant heat exchange between the underside roof and attic floor surfaces. Also included in NBSWHF are the capabilities to determine Fanger's Predicted Mean Vote (PMV), which is a we11-recognized comfort indicator. ${ }^{3}$ Figure 1 shows the calculated and measured indoor temperature and cooling load of the Houston test house for the whole-house-fan operating period covering September 27 through October 1 of 1977. Except for the last day, the measured and NBSWHFcalculated cooling loads are in good agreement.

\section{TEST HOUSES}

Using this validated NBSWHF computer program, the simulation studies were conducted for the Hastings Ranch House (a three-bedroom house with $1,176 \mathrm{ft}^{2}$ floor area), which embodies current energy conservation designs and is more energy efficient than conventional houses. $4 /$ The computer model of the house was, however, modified in accordance with the prevailing local building practices and moved around to the ten cities listed in Table 1 . The essential features of the house are:

Floor:

- 4-inch concrete slab-on-grade over l" rigid foam insulation for California, Arizona, and Texas houses.

- Wooden floor with $\mathrm{R}-7$ insulation over crawl space for the At lanta and Portland houses.

- Basement floor for the Washington, Minneapolis, and Chicago houses.

Roof :

- $22.6^{\circ}$ pitched roof with 1-1/2 ft overhang over the walls.

- R-19 attic floor insulation, except for the Minneapolis house, which had R-22 attic floor insulation. 
Wa11s:

- R-11 insulation with aluminum siding, except for the house in California, which had stucco walls.

Windows:

- Double-glazed windows for Minneapolis, Chicago, Portland, and Washington.

Other data used such as window characteristics, air leakage data, and internal heat source data were made consistent with those used in the DoE's Building Energy Performance Standards (BEPS). Details for the BEPS residential building data are given in reference 4 . The building had $15 \%$ of floor area as the glazing area, which was evenly distributed among all four walls. This assumption was intended to model current practice, in which windows are not preferentially oriented. An internal load of $15: 5 \mathrm{kWh} /$ day was distributed in accordance with a typical household lighting, cooking, appliance-use schedule, as well as the occupancy pattern. As to the air leakage data, it was assumed that the infiltration under standard design condition is 0.6 air change per hour. The hourly air change values, however, were adjusted with respect to actual wind speed and indoor/outdoor temperature difference using the Achenbach and Coblentz relationship. $5 /$

\section{CALCULATED COOLING ENERGY CONSUMPTION}

Tables 2 and 3 show the results of the NBSWHF calculations in terms of annual cooling load comparison between the houses with and without the whole-house fan, determined for the ten cities using ASHRAE TRY weather data tapes.6/

The ASHRAE TRY weather data tapes contain hourly coincident values of outdoor temperature, humidity, wind speed, wind direction, and cloud cover. In NBSWHF the cloud cover data were converted into hourly solar radiation data by the Kimura/Stephenson method.I/

The whole-house fan may be operated in many different ways with regard to starting/stopping, setting of the fan speed, and continuous vs cycling, etc.

In this study, the operation of the whole-house fan was simulated in two different modes. In mode 非 1 , the hourly total volume of the outside air introduced into the house was precisely regulated to satisfy the net sensible cooling requirements of the house for a $78^{\circ} \mathrm{F}$ room temperature set point. This was done in the following sequences:

(1) The hourly sensible cooling requirement without whole-house fan for a given thermostat setting was first determined by a rigorous building heat transfer calculation on an hourly basis.

(2) If the coincident outdoor temperature $\mathrm{DB}$ was below the indoor thermostat setting $78^{\circ}$ and yet higher than $70^{\circ} \mathrm{F}$, the necessary volume of outdoor air to satisfy that cooling requirement was then calculated by the following relation:

$$
\text { cfm }=\frac{\text { Sensible Cooling Requirement }}{1.08(78-\mathrm{DB})} \cdot
$$


(3) The calculation for that hour was then repeated to determine the room and attic temperature under the condition when the air conditioner was off and the whole-house fan would introduce the volume of air determined in step 2 on the basis that the room air was exhausted through the attic space. In order for a given whole-house fan to deliver exactly the right volume of air as determined by the equation in step 2, however, it is intrinsically assumed that the fan is cycled. In other words, the total running time of the fan was assumed proportional to the required cfm as specified in step (2) divided by the full-load capacity of the fan (to deliver an equivalent of 1 air change per minute of the house air.).

The second, iterative calculation showed that the whole-house fan was indeed able to maintain the room temperature at the set value within $1^{\circ} \mathrm{F}$.

(4) The energy consumption of the fan was determined by multiplying the standard power rating (in this example 450 watts) by the fan running time. If the calculated air delivery rate exceeded the rated air delivery rate of the fan, the rated fan air delivery rate was used.

Table 2 also lists the total number of hours of the whole-house fan operation, estimated fan energy consumption, and estimated electrical energy savings on air conditioning (based upon the seasonal COP of 2.5) as a result of the whole-house-fan use, as well as the net seasonal electrical energy savings obtainable by the use of the whole-house fan.

In typical applications, however, the whole-house fan is not cycled by the room thermostat as simulated in the mode 1 l calculation. It is operated continuously with full capacity of one air change per minute as long as the outdoor temperature is above $78^{\circ} \mathrm{F}$ but below $82^{\circ} \mathrm{F}$, with the room air conditioner turned off. This mode of operation, designated as mode 2 , was simulated using NBSWHF. The whole-house fan in the mode 2 analysis is also assumed to operate at half capacity (i.e., 0.5 air change per minute) when the outdoor temperature is below $78^{\circ} \mathrm{F}$ but above $72^{\circ} \mathrm{F}$. When the outdoor temperature was below $72^{\circ} \mathrm{F}$ it was also assumed that the fan was stopped and the house was cooled with natural ventilation of 6 air changes per hour, or one-tenth of the standard whole-house-fan rate. The indoor temperature will be very close to the outdoor temperature when the whole-house fan is introducing the outdoor air with a rate of one air change per minute, which would create a breeze of $100200 \mathrm{ft}$ per minute. The breeze makes the occupant comfortable under higher temperatures than $80^{\circ} \mathrm{F}$, as shown in Figure 2, which depicts the Fanger comfort index. The PMV stands for the "Predicted Mean Vote" and represents the average thermal sensation of people representing many social strata and age groups on the combined effect of temperature, humidity, mean radiant temperature, and air speed across the body. The scale for the PMV is as follows: 


$\begin{array}{rll}3 & \text { hot } \\ 2 & \text { warm } & \\ 1 & \text { slightly } & \text { warm } \\ 0 & \text { neutral } & \\ -1 & \text { slightly } & \text { cool } \\ -2 & \text { cool } & \\ -3 & \text { cold. }\end{array}$

The physiological fundamentals of PMV with respect to thermal environment, effect of sex, race, age, food and other factors are given in reference 3 . Figure 2 shows also that the full-capacity whole-house-fan breeze (100 200 fpm) would make the occupant feel too cool if the room temperature were below $80^{\circ} \mathrm{F}$. This is the reason that the fan capacity was assumed to be cut down to a half of full capacity. Furthermore, it was assumed that the natural ventilation without fan could provide approximately 6 air changes per hour of outdoor air circulation and is good enough to provide a comfortable condition when the outdoor temperature is below $72^{\circ} \mathrm{F}$ but above $65^{\circ} \mathrm{F}$.

Table 3 shows the result of the mode 非 calculations for the same houses used in the mode 非 1 simulation. A marked increase in the electric energy savings is mostly due to the fact that the number of hours when the fan is on (WHF hours) to replace the air conditioner is larger than in the mode 非 operation. The increase of the cooling $\mathrm{kWh}$ savings was, however, somewhat offset by the increased fan energy consumption. The fan power in this case was estimated by examining typical commercial whole-house fan ratings and was assumed to be 450 watts at full capacity and 130 watts at half capacity. It appears that the electrical power consumption varies with 1.7 power of air delivery rate while the theoretical fan brake horse power should vary with the cubic power of the air delivery rate, in accordance with the fan law. The deviation from the fan law is due to the reduction in the electrical motor efficiency as its rpm is reduced.

Figures 3 through 12 show the daily cooling kWh plotted versus daily average outdoor temperature for the ten cities used in the analysis. For this

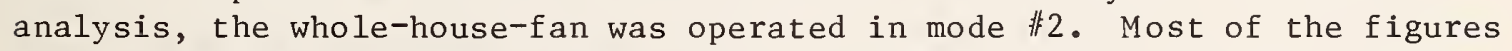
show the marked decrease of the daily cooling kWh when the whole-house-fan was utilized, except for Phoenix and Fresno, where the cooling kWh savings are somewhat smaller than in the other cities. This is because the percentage of possible whole-house fan hours during the summer in these two cities is considerably smaller than in the other cities, as shown in Table 1 and Figure 24. The two straight lines shown in these figures are least-squares-fit representations of the calculated daily total cooling kWh points.

Figures 13 through 22 show the hourly frequency of calculated PMV's for the houses with and without the use of whole-house ventilation. These hourly frequency profiles under shaded histogram represent the house without whole-house fan, while the unshaded histograms represent the house with whole-house fan. The house with a whole-house fan operated under mode 2 tends to show many hours with higher PMVs. The PMVs in these calculations, however, were calculated on the basis of a predetermined set of occupancy responses to the hot environments as follows: 
1) The occupant wears typical business suit $(c 10=1.0)$. The room air motion is zero.

2) When the occupant feels warm as the indoor temperature increases $(P M V=2.0)$, he starts shedding his clothes until the clo value becomes 0.5 or the equivalent of light summer clothing.

3) If the PMV value is still higher than 2.0 at clo $=0.5$, the PMV is recalculated with increased air speeds at steps of $0.1 \mathrm{~m} / \mathrm{s}$ until $0.5 \mathrm{~m} / \mathrm{s}$ is reached.

In figures 13 through 22, the PMV values in the abscissa are shown to represent these three conditions. Although these figures clearly indicate that the use of whole-house fans would shift the comfort profile toward "warm," a majority of occupants would be comfortable even during the hottest period of the season by wearing light clothes and staying in the breezy areas in the house. The same figures also indicate that the whole-house fan would make the occupant feel cool in many hours during the year unless he wears heavy clothes and stays in nonbreezy areas.

The higher PMV values shown in Figures 13 through 22, especially for the whole-house fan calculation, could therefore be reduced by as much as 1.0 , if they were evaluated at $0.5 \mathrm{clo}$ and at $0.5 \mathrm{~m} / \mathrm{s}$ (or approximately $100 \mathrm{fpm}$ ) instead of zero. In other words, a thermal comfort level of about 1.0 (slightly warm condition) could be maintained throughout the summer for all of the whole-house-fan houses in the United States.

In order to compare the cooling $\mathrm{kWh}$ effectiveness of the whole-house fan at indoor thermostat settings other than $78^{\circ} \mathrm{F}$, figure 23 is prepared for the Washington, D.C. ranch house. This figure was obtained for the mode 1 condition so that the effectiveness of the whole-house fan could be compared at identical indoor conditions. It is shown also that the relative amount of cooling kWh saving becomes greater as the indoor cooling thermostat is set at a higher temperature. The implication of this particular figure is that an equal or greater amount of cooling kWh savings can be obtained simply by increasing the cooling thermostat setting without even using a whole-house fan. For example, the annual cooling $\mathrm{kWh}$ reduction by whole-house fan at $78^{\circ} \mathrm{F}$ for the Washington D.C. ranch house is from $2500 \mathrm{kWh}$ to $1900 \mathrm{kWh}$, or $600 \mathrm{kWh}$. Figure 23 shows that the same kWh savings can be obtained by simply turning the thermostat from $78^{\circ}$ to $82^{\circ} \mathrm{F}$. The comfort aspect at $82^{\circ} \mathrm{F}$ can be made similar to that of $78^{\circ} \mathrm{F}$ by using ceiling fan or similar room circulating fan as long as the room humidity level is not excessive.

This point merits attention for economic considerations, since the cost of purchasing and installing a whole-house fan is not trivial. 


\section{CONCLUSIONS}

A large amount of net cooling energy savings -- as much as 56 percent -- is possible by replacing the air conditioner with a whole-house fan, without causing undue thermal discomfort.

Cooling energy savings by the use of a whole-house fan appear to be less effective in desert climates such as Phoenix and Fresno, than in other cities. It is generally true that the cooling $\mathrm{kWh}$ savings become greater as the number of potential hours for whole-house ventilation increases, as shown in Figure 23.

More studies are needed to develop the sensitivities of major parameters and the effectiveness of whole-house cooling -- such as house thermal mass, indoor thermostat setting, and size of the whole-house fan. Also to be included in the future studies are economic analyses as well as the indoor relative humidity problems (when the outdoor air humidity level is high).

\section{REFERENCES}

1. D.M. Burch and S.J. Treado, "Ventilating Residences and Their Attics for Energy Conservation," Summer Attic and Whole-House Ventilation, NBS Special Publication 548, pp. 73-104, June 1979.

2. T. Kusuda, "NBSLD, the Computer Program for Heating and Cooling Loads in Buildings," NBS Building Science Series 69, July 1976.

3. P.O. Fanger, "Thermal Comfort -- Analysis and Applications in Environmental Engineering." McGraw-Hill Book Co., 1972.

4. M. Levine, "Economical Analysis of Proposed Building Energy Performance Standards," Lawrence Berkeley Laboratory Report PNL 3044, Sept. 1979.

5. C. Coblentz and P.R. Achenbach, "Field Measurements of Air Infiltration in Ten Electrically Heated Houses." ASHRAE Transactions 69, 1963.

6. E. Stamper, "Weather Data," ASHRAE Journal, p. 47, Feb. 1977.

7. K. Kimura and D. G. Stephensen, "Solar Radiation on Cloudy Days," ASHRAE Transactions 75, Part I, pp. 227-233, 1969. 
Table 1. Number of Hours During the Year When Temperature Falls Within Various Temperature Bins

\begin{tabular}{|c|c|c|c|c|c|c|}
\hline ocations & $65-71$ & $72-77$ & $78-82$ & above 8 & above 72 & col 5 \\
\hline At lanta, GA & 1878 & 1217 & 663 & 439 & 2319 & $81 \%$ \\
\hline Burbank, CA & 1967 & 528 & 67 & 53 & 648 & $92 \%$ \\
\hline Chicago, IL & 1102 & 717 & 330 & 275 & 1322 & $79 \%$ \\
\hline Fresno, CA & 1087 & 745 & 526 & 1195 & 2466 & $52 \%$ \\
\hline Ft. Worth, TX & 1117 & 1378 & 934 & 1422 & 3754 & $62 \%$ \\
\hline Houston, TX & 1374 & 1808 & 1160 & 1244 & 4212 & $70 \%$ \\
\hline Minneapolis, MN & 906 & 704 & 389 & 452 & 1545 & $71 \%$ \\
\hline Phoenix, AR & 1157 & 900 & 718 & 2422 & 4040 & $40 \%$ \\
\hline Portland, OR & 755 & 345 & 192 & 138 & 675 & $78 \%$ \\
\hline Washington, DC & 1110 & 1008 & 601 & 722 & 2331 & $69 \%$ \\
\hline
\end{tabular}

* The bin data were generated from ASHRAE TRY (Test Reference Year) weather data tapes.

Table 2. Annual Cooling Requirement of Hastings Rarich House With and Without the Use of Whole-House Fan (WHF)

Control Mode 非 1 (Whole-house fan cycled by room thermostat)

\begin{tabular}{|c|c|c|c|c|c|c|c|}
\hline \multirow[b]{2}{*}{ Locations } & \multicolumn{2}{|c|}{$\begin{array}{c}\text { Annual Cooling } \\
\mathrm{kWh}\end{array}$} & \multirow{2}{*}{$\begin{array}{l}\text { WHF Hours } \\
\text { of } \\
\text { Operation }\end{array}$} & \multirow{2}{*}{$\begin{array}{c}\text { Cooling } \\
\text { Savings } \\
\text { kWh } \\
\end{array}$} & \multirow{2}{*}{$\begin{array}{l}\text { Estimated* } \\
\text { Fan Power } \\
\text { Consumption } \\
\text { kWh }\end{array}$} & \multicolumn{2}{|c|}{$\begin{array}{l}\quad \text { Net Savings } \\
\text { Electric Energy } \\
\end{array}$} \\
\hline & $\begin{array}{l}\text { Wi thout } \\
\text { WHF } \\
\end{array}$ & $\begin{array}{l}\text { With } \\
\text { WHF }\end{array}$ & & & & $\mathrm{kWh}$ & $\%$ \\
\hline Atlanta, GA & 3098 & 2056 & 288 & 1042 & 130 & 912 & 29.4 \\
\hline Burbank, CA & 1870 & 1444 & 107 & 426 & 48 & 378 & 20.2 \\
\hline Chicago, IL & 1725 & 1189 & 173 & 536 & 78 & 548 & 26.6 \\
\hline Fresno, CA & 2845 & 2342 & 182 & 503 & 82 & 421 & 14.8 \\
\hline Ft. Worth TX & 3894 & 2992 & 275 & 902 & 124 & 778 & 20.0 \\
\hline Houston, TX & 4394 & 3172 & 361 & 1222 & 162 & 1068 & 24.1 \\
\hline Minneapolis, MN & 1853 & 1332 & 162 & 521 & 73 & 448 & 24.2 \\
\hline Phoenix, AR & 4580 & 4078 & 182 & 502 & 82 & 420 & 9.2 \\
\hline Portland, OR & 1347 & 1025 & 90 & 322 & 41 & 281 & 20.9 \\
\hline Washington, DC & 2567 & 1859 & 201 & 708 & 90 & 618 & 24.1 \\
\hline
\end{tabular}

* Assumed fan size 450 watt 
Table 3. Annual Cooling Requirement of Hastings Ranch House With and Without the Use of Whole-house Fan

$\underline{\text { Locations }}$

Control Mode \#2 (stepwise fan speed control)*

\begin{tabular}{|c|c|c|c|c|c|c|c|}
\hline \multirow[b]{2}{*}{ Locations } & \multicolumn{2}{|c|}{$\begin{array}{l}\text { Annual Cooling } \\
\mathrm{kWh}\end{array}$} & \multirow{2}{*}{$\begin{array}{c}\text { WHF Hours } \\
\text { of } \\
\text { Operation }\end{array}$} & \multirow{2}{*}{$\begin{array}{c}\text { Cooling } \\
\text { Savings } \\
\mathrm{kWh}\end{array}$} & \multirow{2}{*}{$\begin{array}{c}\text { Estimated* } \\
\text { Fan Power } \\
\text { Consumption } \\
\text { kWh } \\
\end{array}$} & \multicolumn{2}{|c|}{$\begin{array}{c}\text { Net Savings } \\
\text { Electric Energy }\end{array}$} \\
\hline & $\begin{array}{l}\text { Without } \\
\text { WHF }\end{array}$ & $\begin{array}{l}\text { With } \\
\text { WHF }\end{array}$ & & & & $\mathrm{kWh}$ & $\%$ \\
\hline Atlanta, GA & 3098 & 879 & 1880 & 2219 & 469 & 1750 & 56.4 \\
\hline Burbank, CA & 1870 & 961 & 595 & 909 & 124 & 785 & 42.0 \\
\hline Chicago, IL & 1725 & 629 & 1047 & 1096 & 249 & 847 & 49.1 \\
\hline Fresno, CA & 2845 & 1722 & 1271 & 1123 & 341 & 782 & 27.5 \\
\hline Ft. Worth, TX & 3894 & 2037 & 2312 & 1857 & 613 & 1244 & 31.9 \\
\hline Houston, TX & 4394 & 1834 & 2968 & 2560 & 775 & 1785 & 40.6 \\
\hline Minneapolis, MN & 1853 & 755 & 1093 & 1098 & 274 & 824 & 44.5 \\
\hline Phoenix, AR & 4580 & 3356 & 1618 & 1224 & 449 & 775 & 16.9 \\
\hline Portland, OR & 1347 & 655 & 537 & 692 & 135 & 554 & 41.3 \\
\hline Washington, DC & 2567 & 1094 & 1609 & 1473 & 412 & 1061 & 41.3 \\
\hline
\end{tabular}

* $\mathrm{DB}>82$ air conditioner with no whole-house fan $0.6 \mathrm{AC} / \mathrm{hr}$ $82>\mathrm{DB}>78$ no air conditioner with whole-house fan $60 \mathrm{AC} / \mathrm{hr}$ $78>\mathrm{DB}>72$ no air conditioner with whole-house fan $30 \mathrm{AC} / \mathrm{hr}$

$72>\mathrm{DB}$ natural ventilation, no air conditioner and no whole-house fan, $6 \mathrm{AC} / \mathrm{hr}$

when $\mathrm{DB}=$ outdoor temperature 


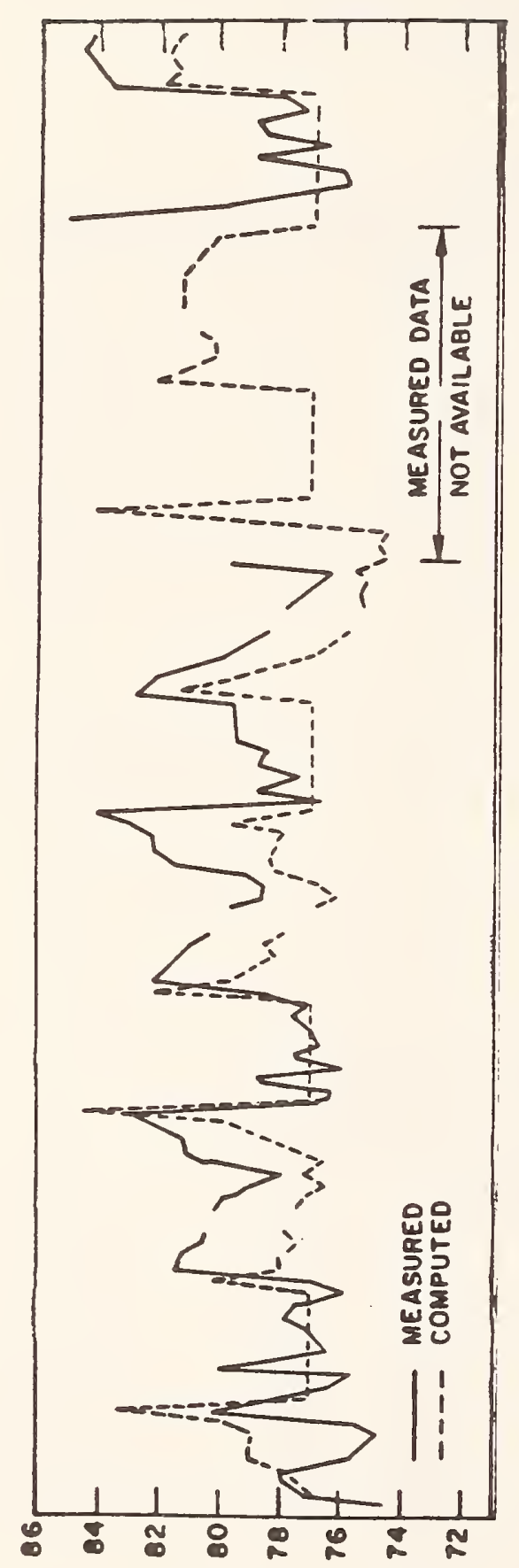

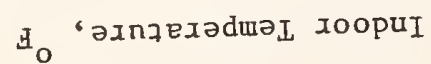

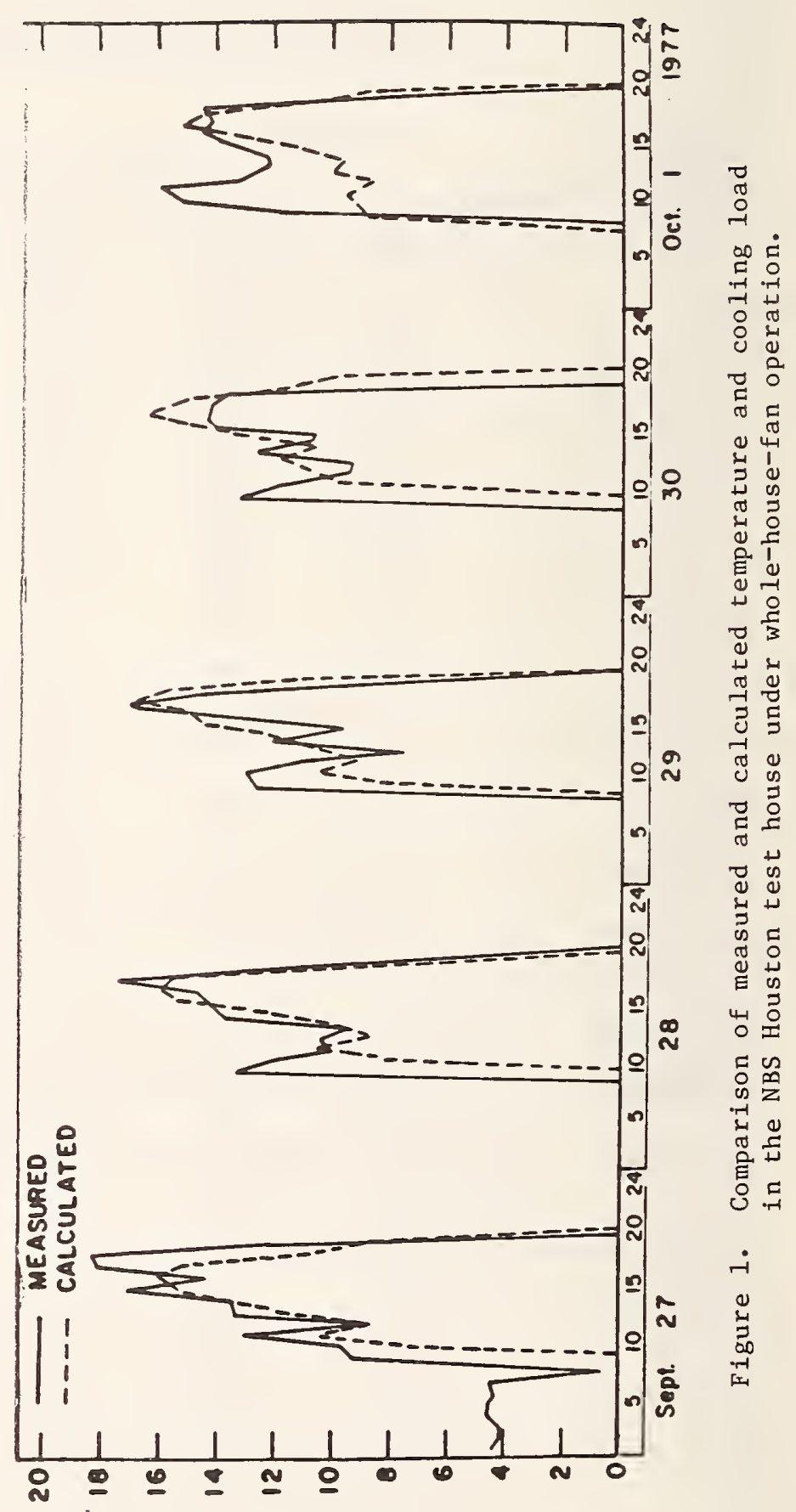

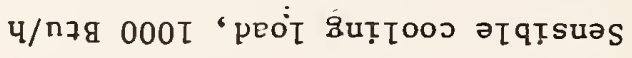




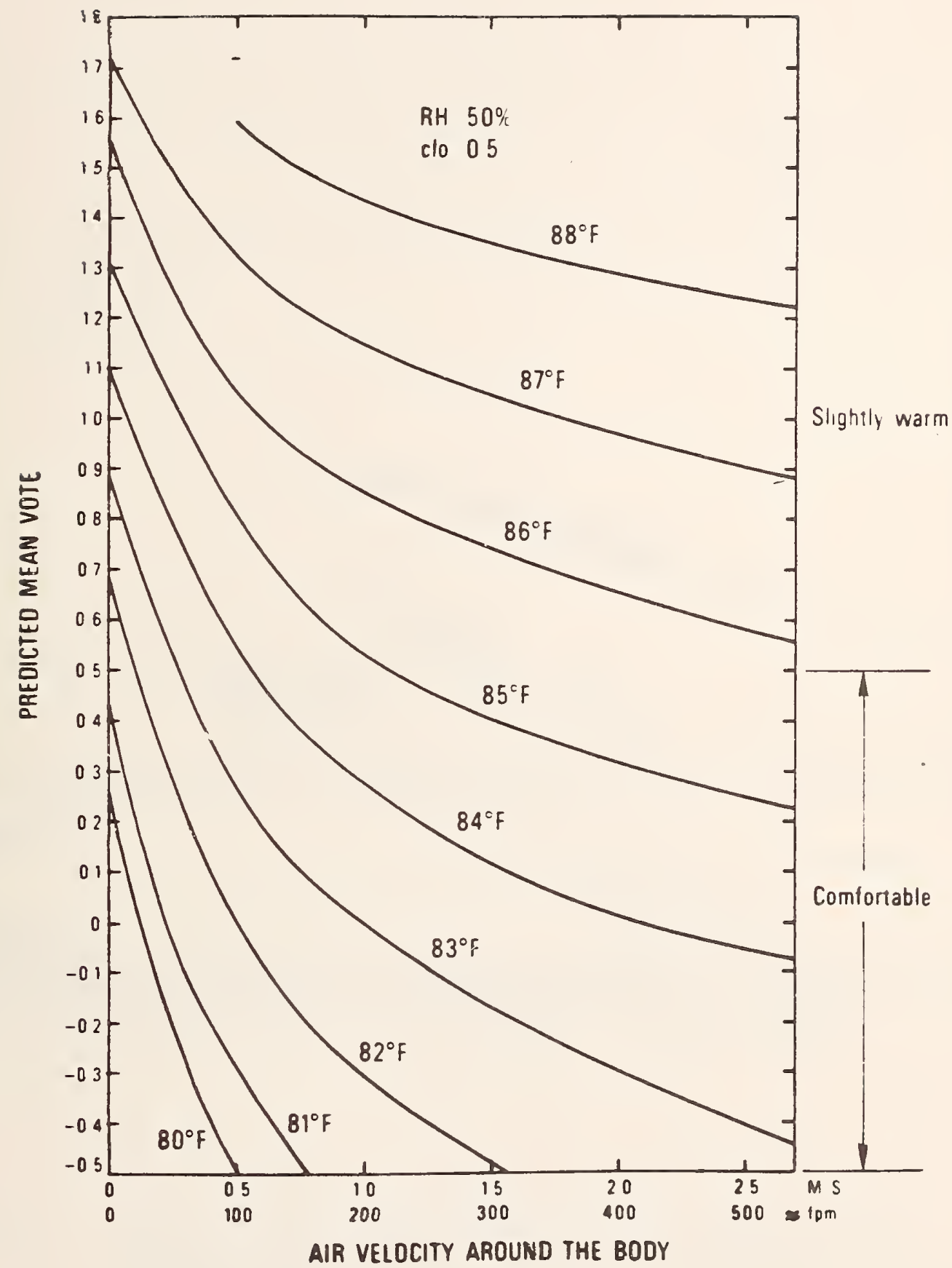

Figure 2. Fanger's comfort index with respect to air speed around the body. 


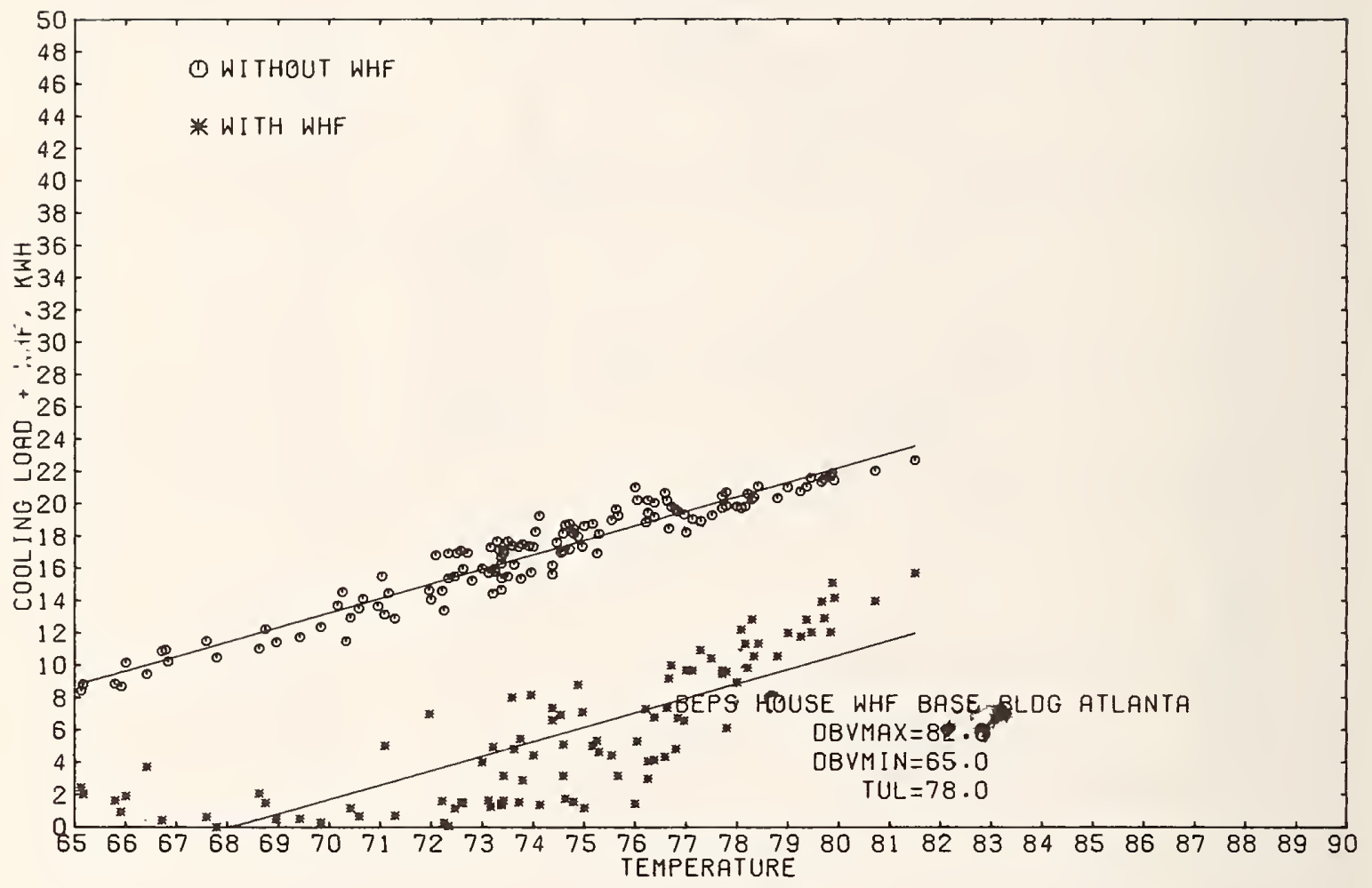

Figure 3. Predicted daily total cooling energy consumption vs. daily average outdoor temperature for a typical ranch house in Atlanta, GA with and without the use of whole-house fan (WHF). 


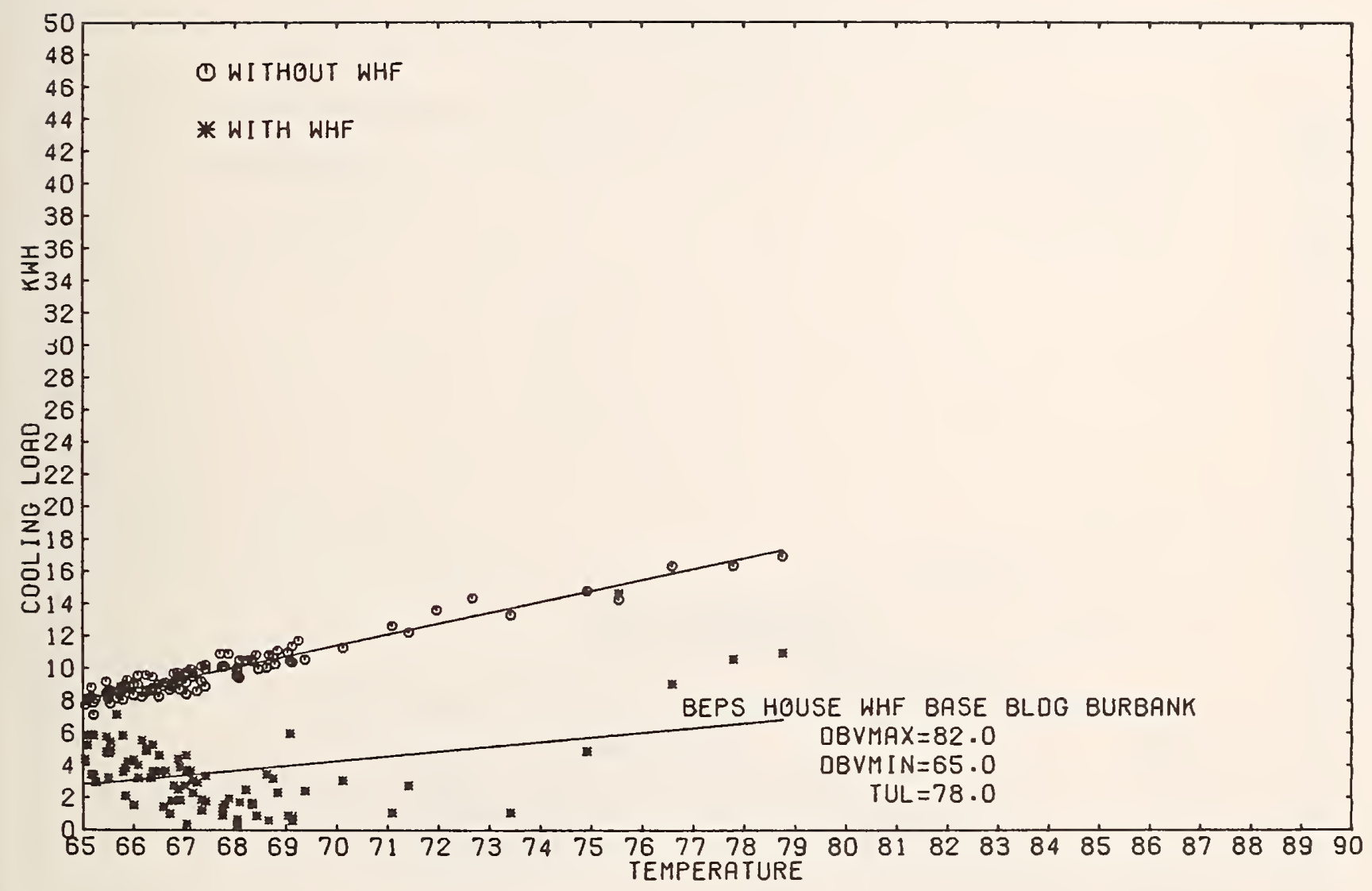

Figure 4. Predicted daily total cooling energy consumption vs. daily average outdoor temperature for a typical ranch house in Burbank, CA with and without the use of whole-house fan (WHF). 


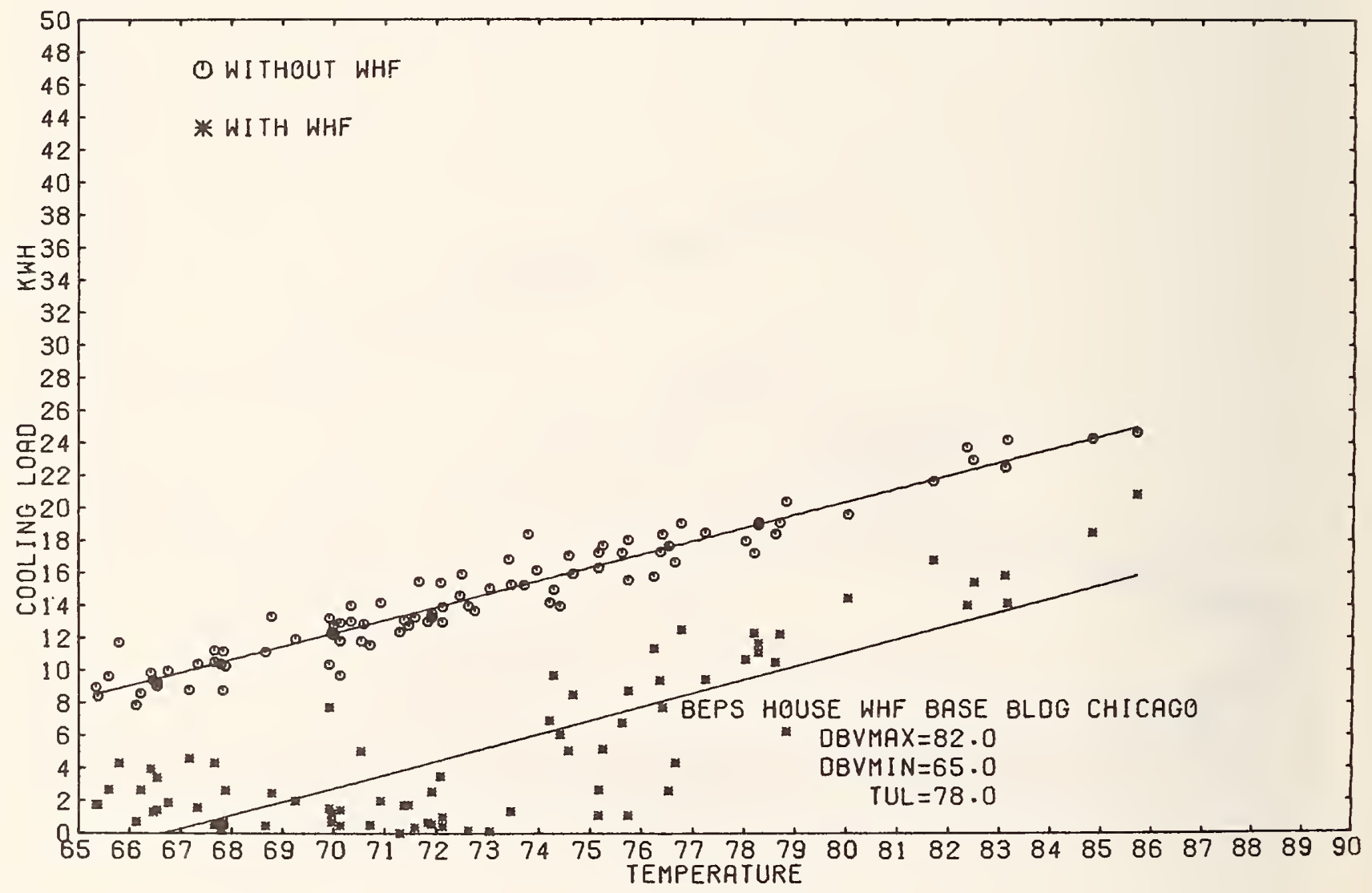

Figure 5. Predicted daily total cooling energy consumption vs. daily average outdoor temperature for a typical ranch house in Chicago, IL with and without the use of whole-house fan (WHF). 


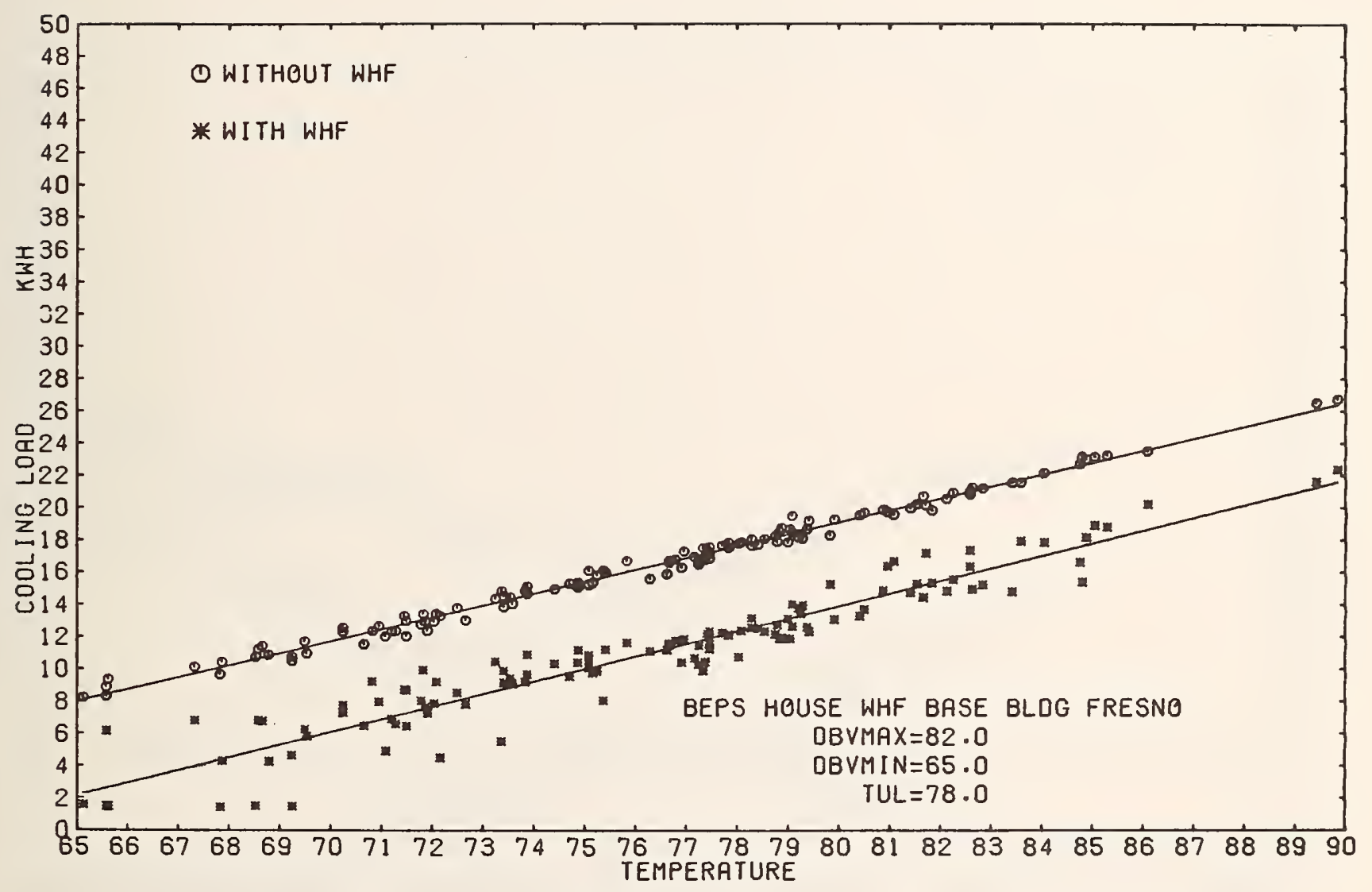

Figure 6. Predicted daily total cooling energy consumption vs. daily average outdoor temperature for a typical ranch house in Fresno, CA with and without the use of whole-house fan (WHF). 


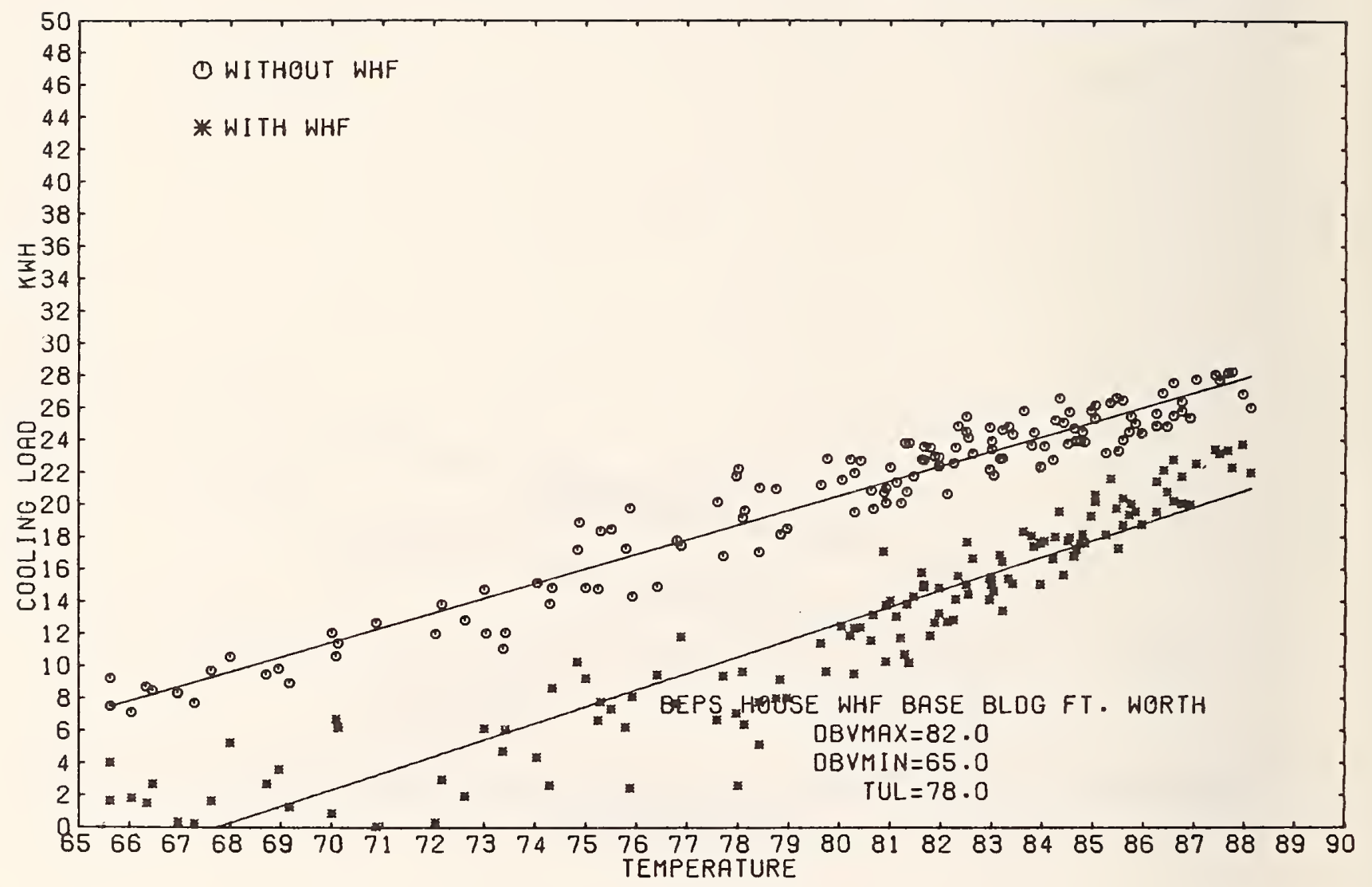

Figure 7. Predicted daily total cooling energy consumption vs. daily average outdoor temperature for a typical ranch house in Ft. Worth, TX with and without the use of whole-house fan (WHF). 


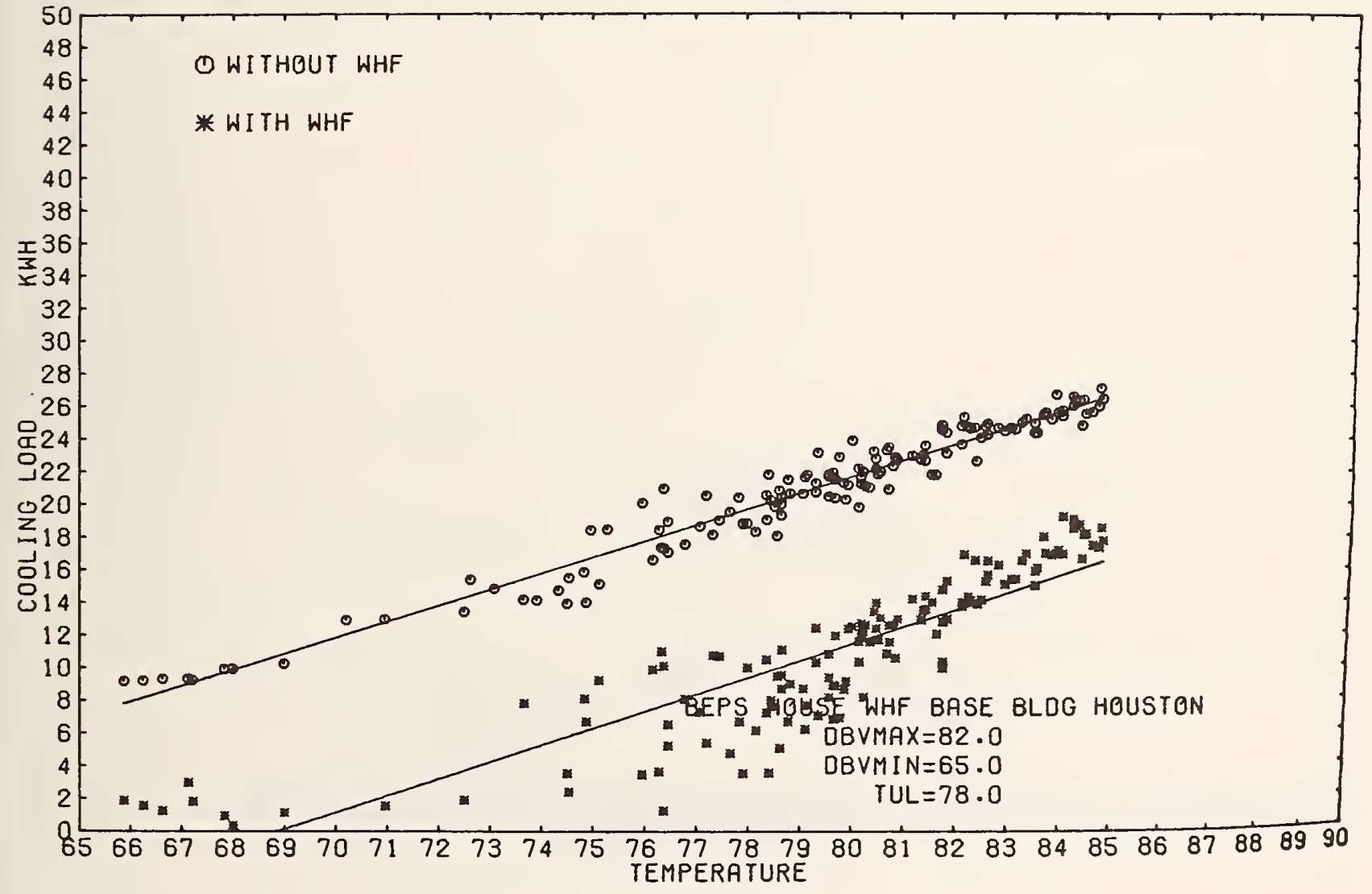

Figure 8. Predicted daily total cooling energy consumption vs. daily average outdoor temperature for a typical ranch house in Houston, TX with and without the use the whole-house fan (WHF). 


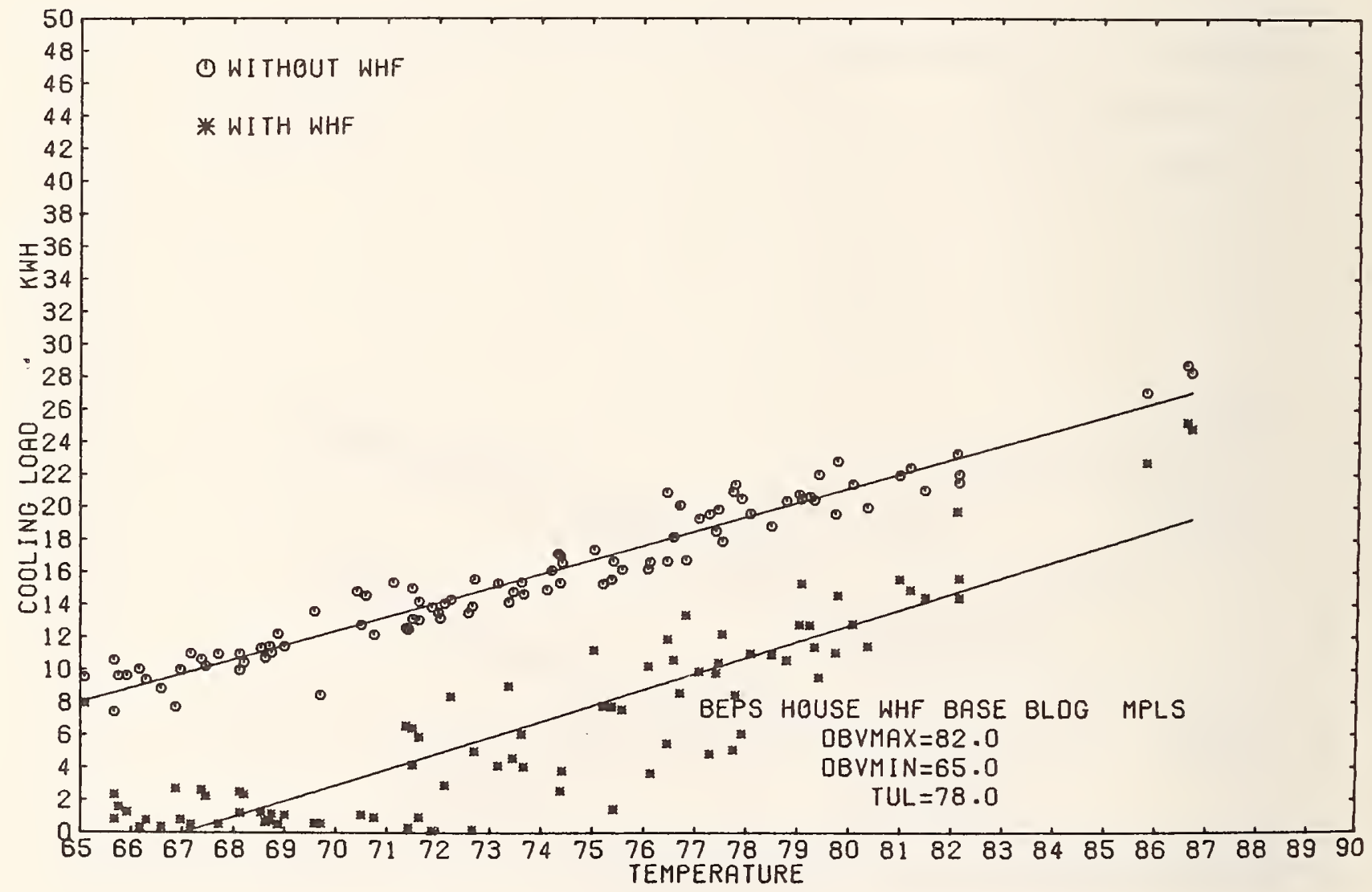

Figure 9. Predicted daily total cooling energy consumption vs. daily average outdoor temperature for a typical ranch house in Minneapolis, MN with and without the use of whole-house fan (WHF). 


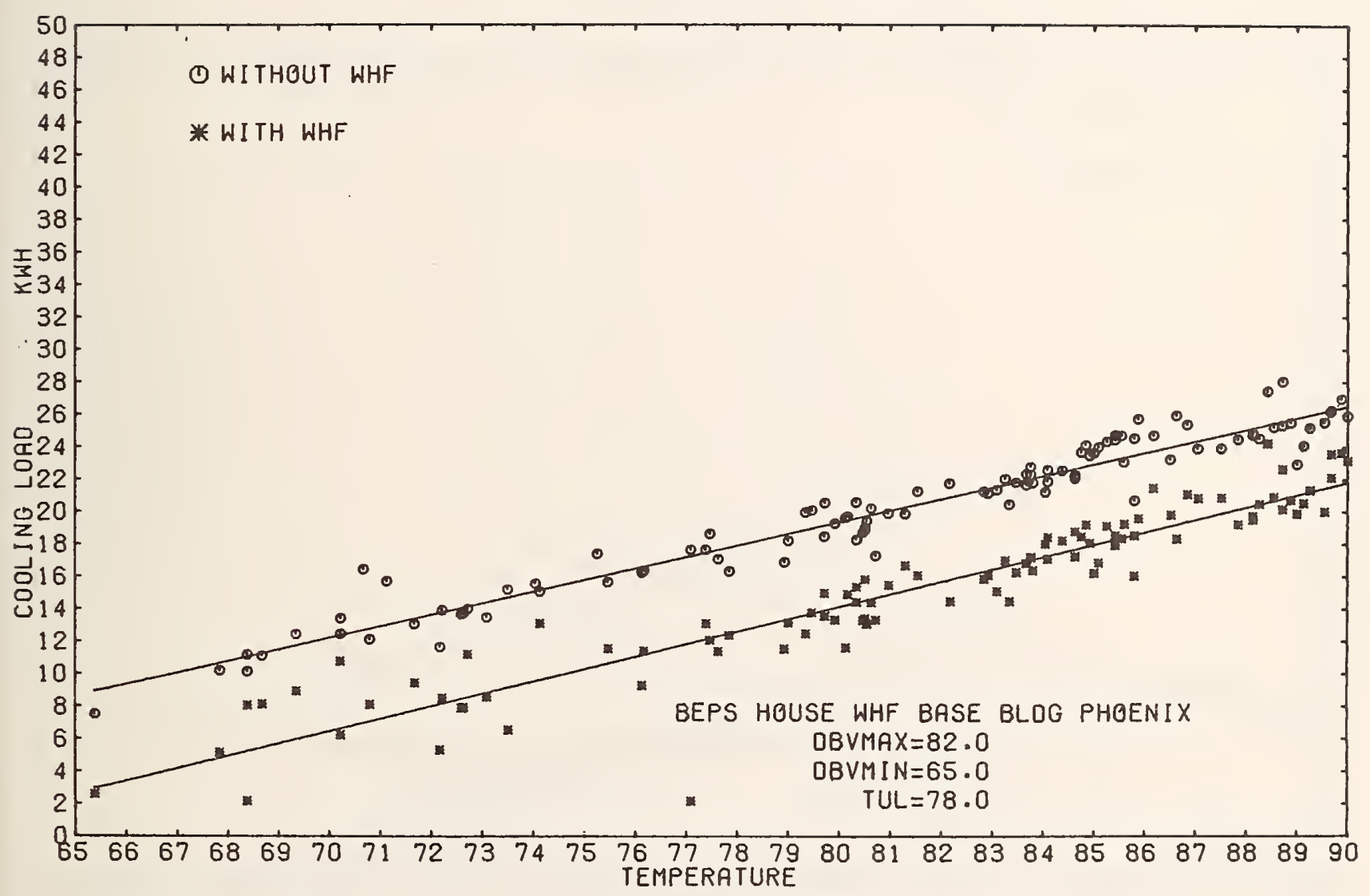

Figure 10. Predicted daily total cooling energy consumption vs. daily average outdoor temperature for a typical ranch house in Phoenix, AZ with and without the use of whole-house fan (WHF). 


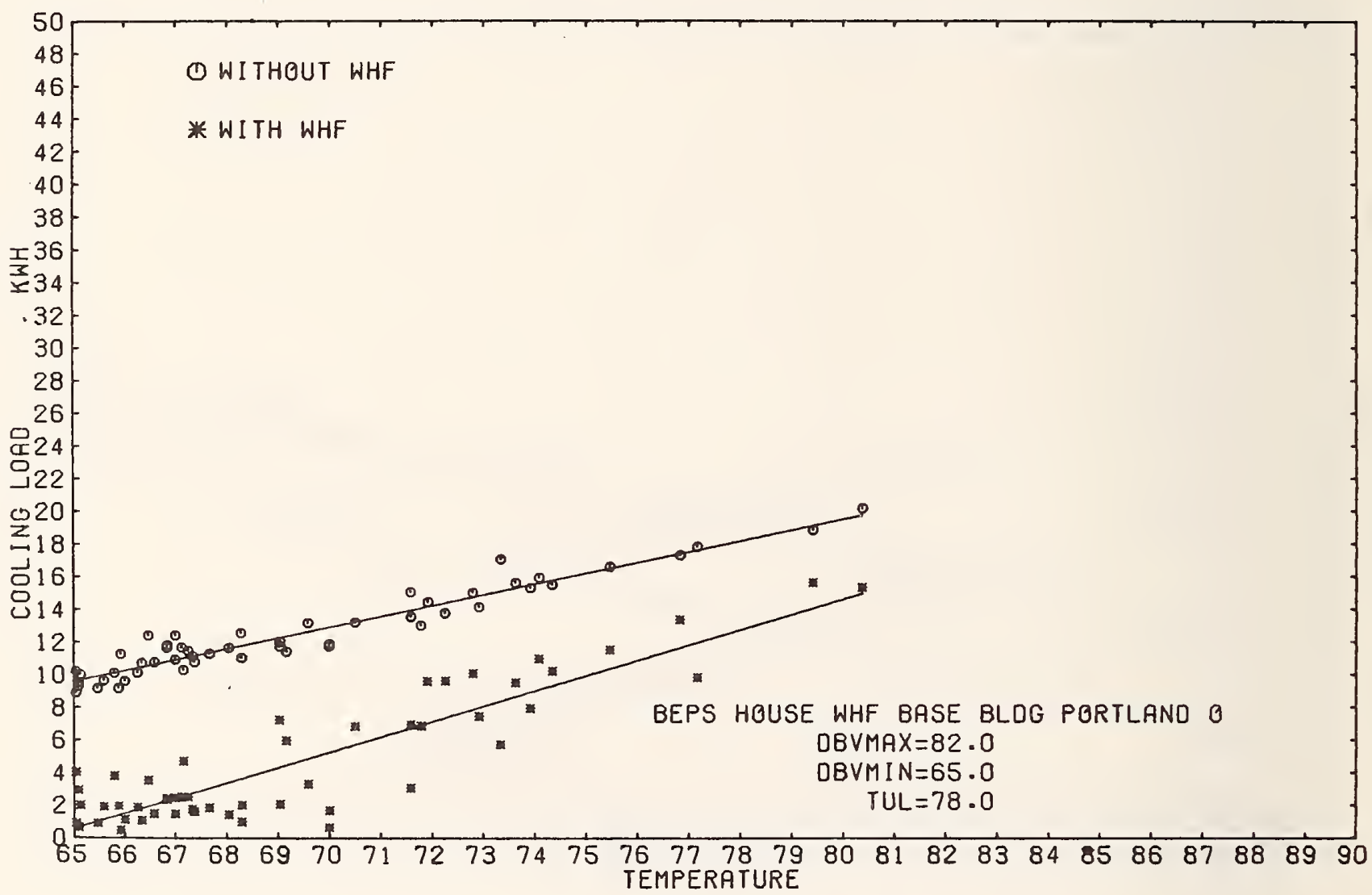

Figure 11. Predicted daily total cooling energy consumption vs. daily average outdoor temperature for a typical ranch house in Portland, OR with and without the use of whole-house fan (WHF). 


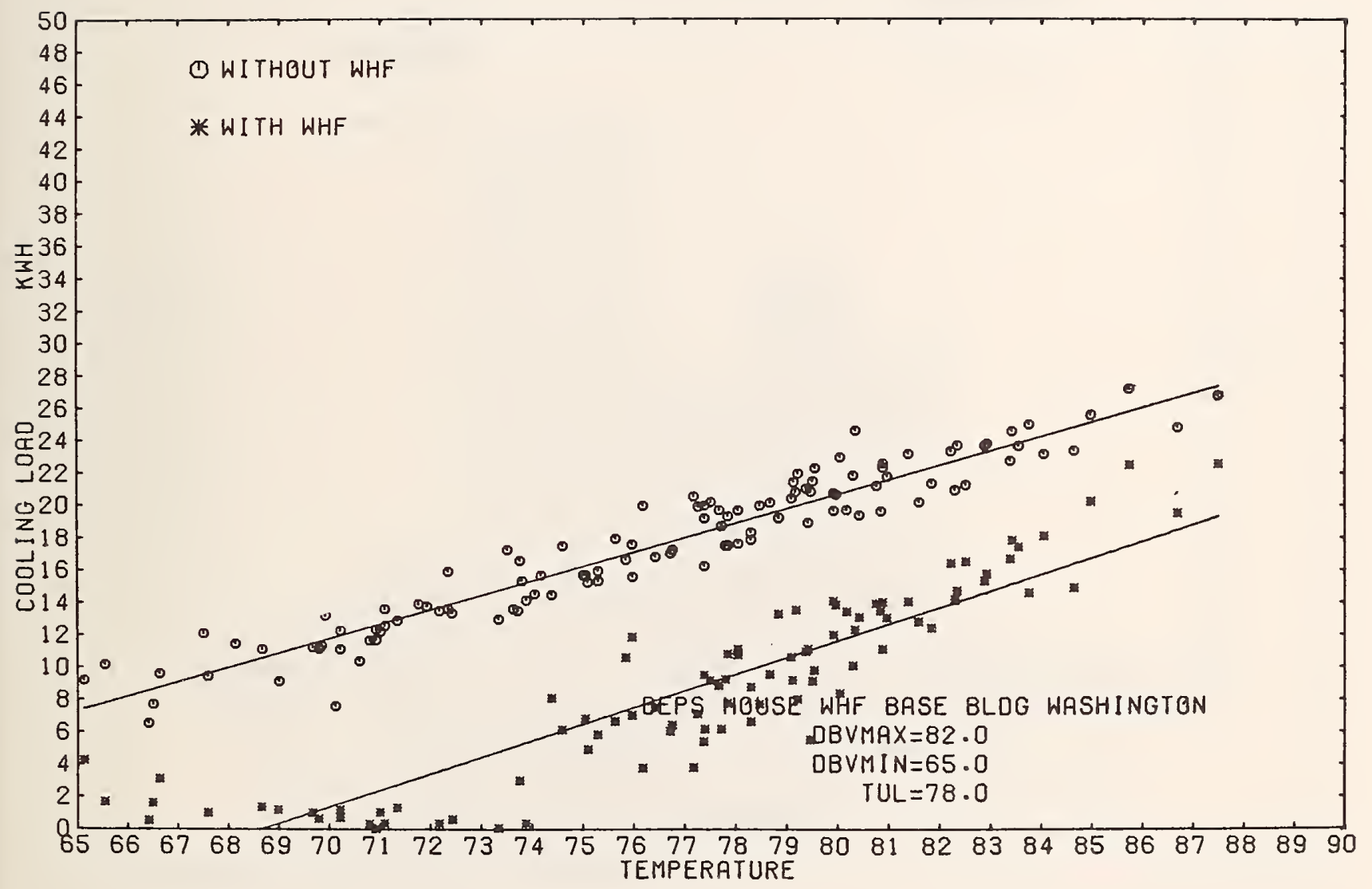

Figure 12. Predicted daily total cooling energy consumption vs. daily average outdoor temperature for a typical ranch house in Washington, DC with and without the use of whole-house fan (WHF). 


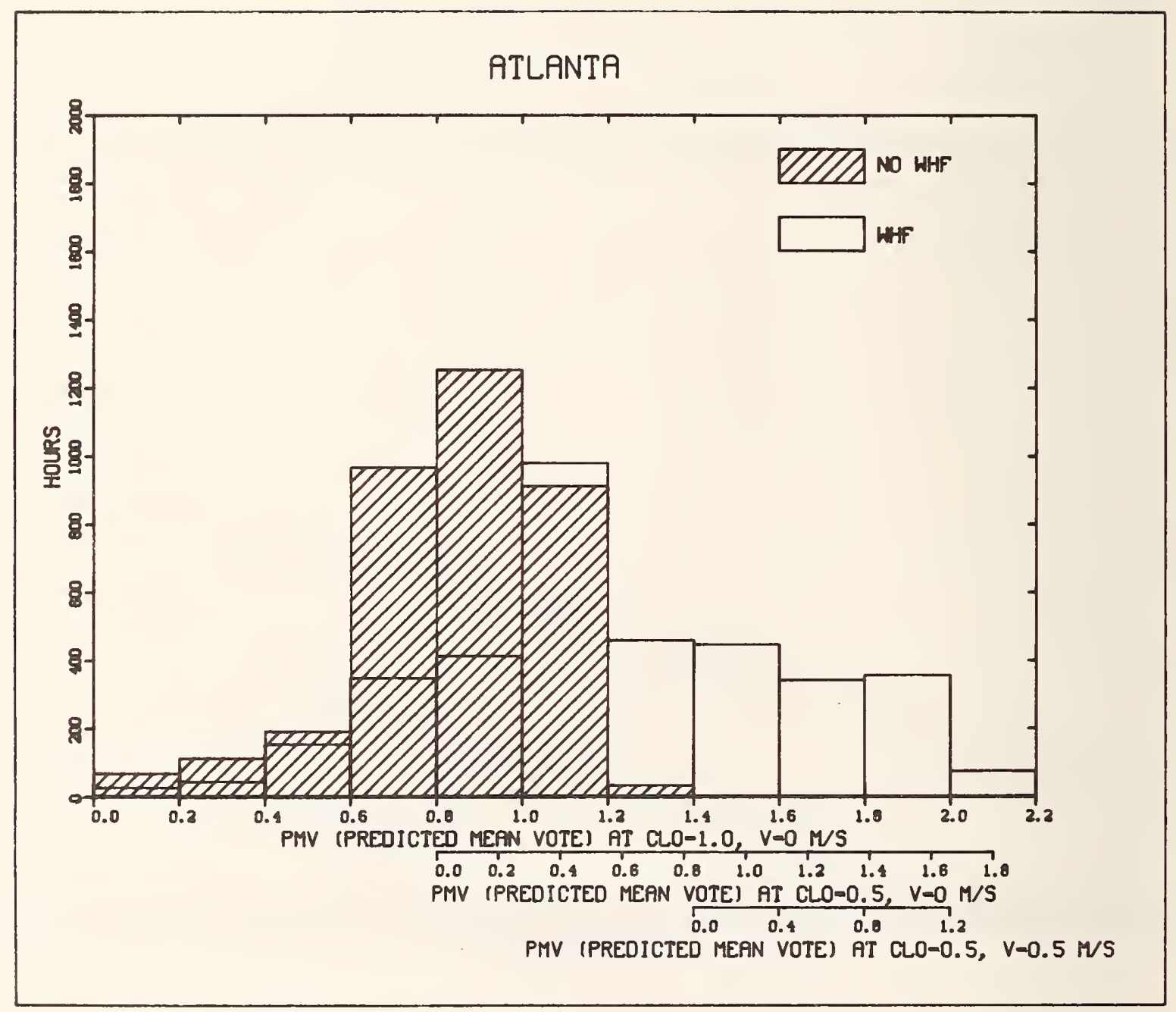

Figure 13. Predicted hourly frequency of comfort index in a typical ranch house in Atlanta, GA with and without the use of whole-house fan (WHF).

PMV =Fanger's Predicted Mean Vote

$P M V=0$ comfortable; $P M V=1$ slightly warm; $P M V=2$ warm. 


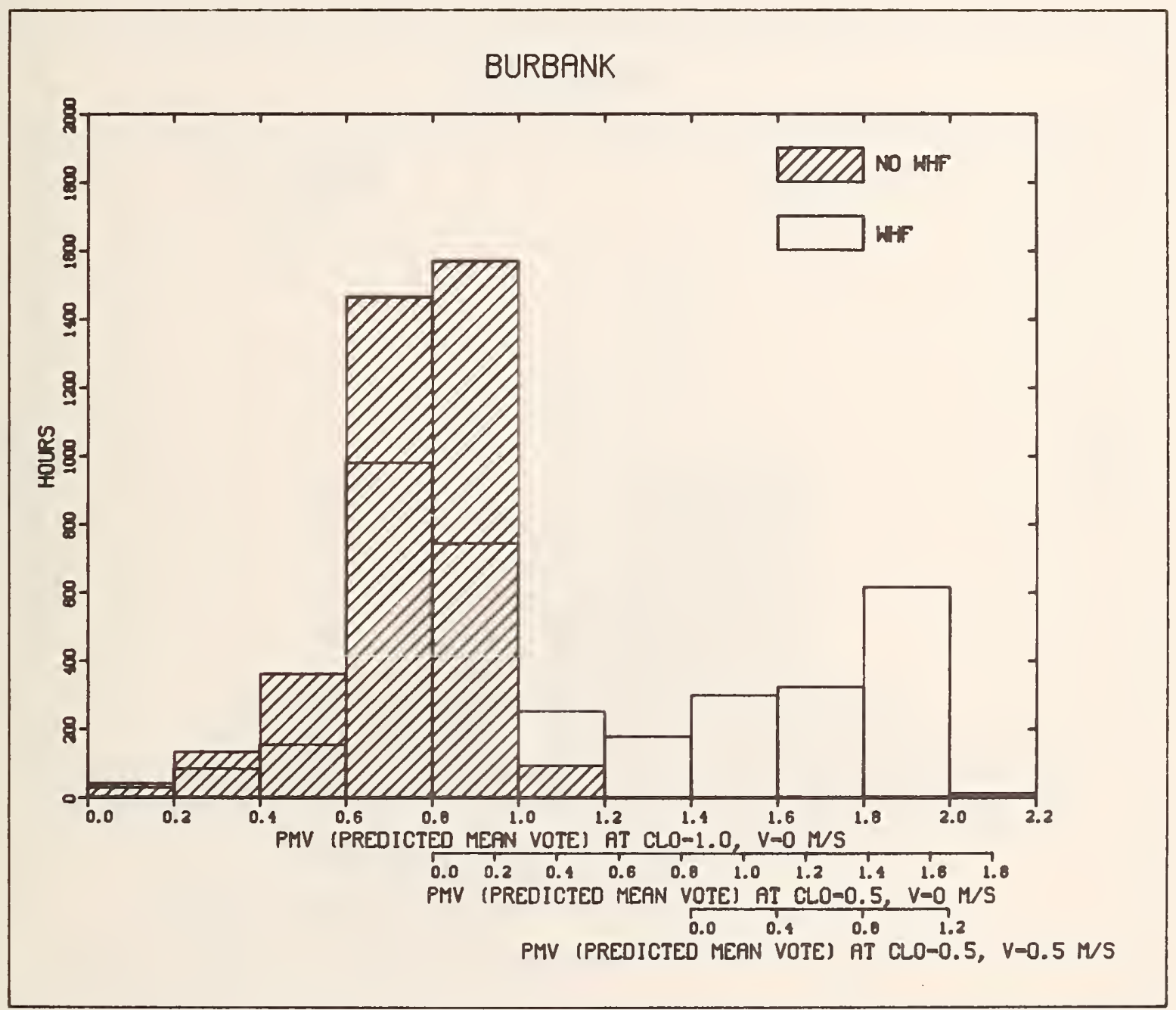

Figure 14. Predicted hourly frequency of comfort index in a typical ranch house in Burbank, $C A$ with and without the use of whole-house fan (WHF).

PMV=Fanger's Predicted Mean Vote $P M V=0$ comfortable; $P M V=1$ slightly warm; $P M V=2$ warm. 


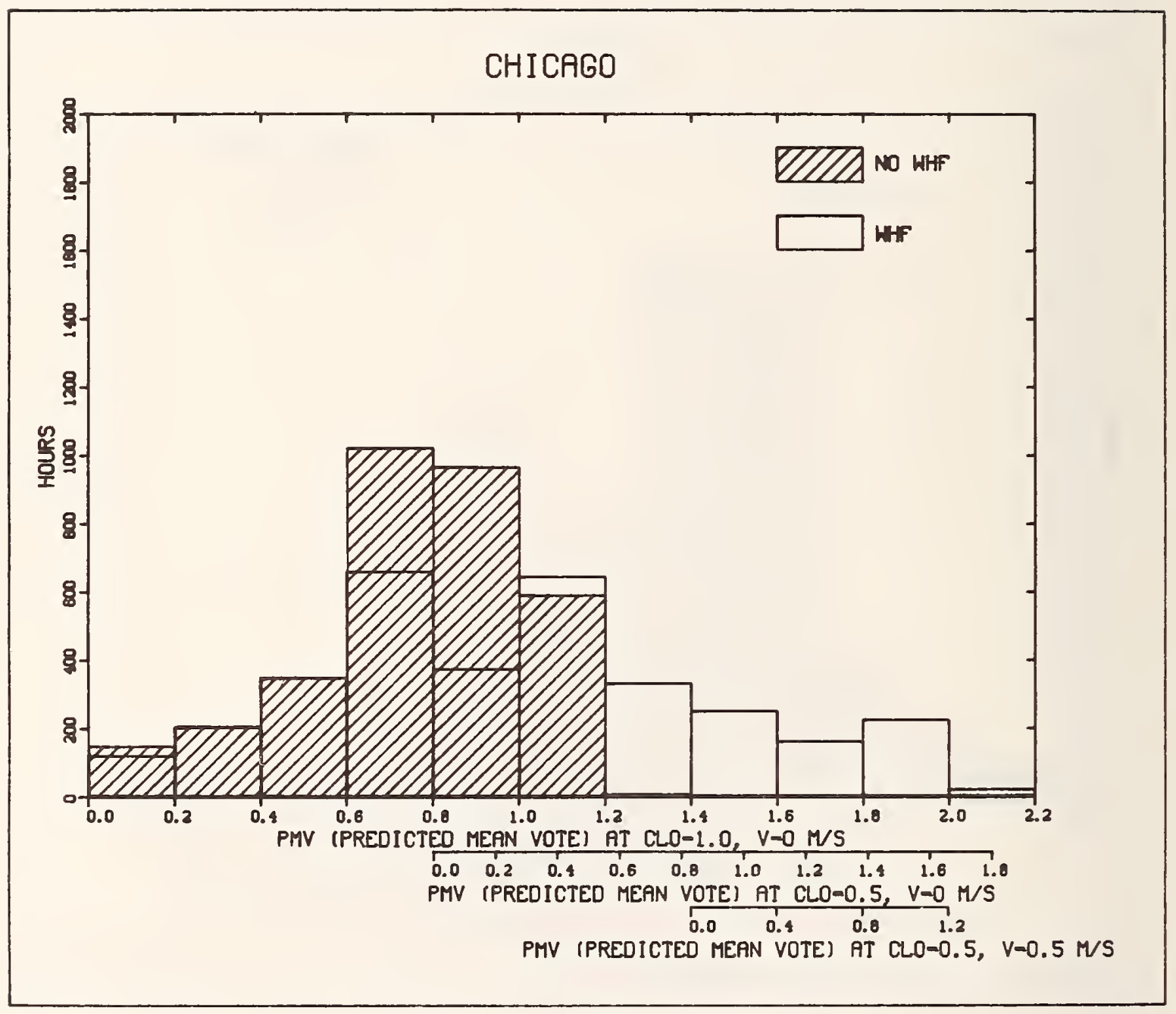

Figure 15. Predicted hourly frequency of comfort index in a typical ranch house in Chicago, IL with and without the use of whole-house fan (WHF).

$\mathrm{PMV}=$ Fanger's Predicted Mean Vote

$P M V=0$ comfortable; PMV=1 slightly warm; PMV=2 warm. 


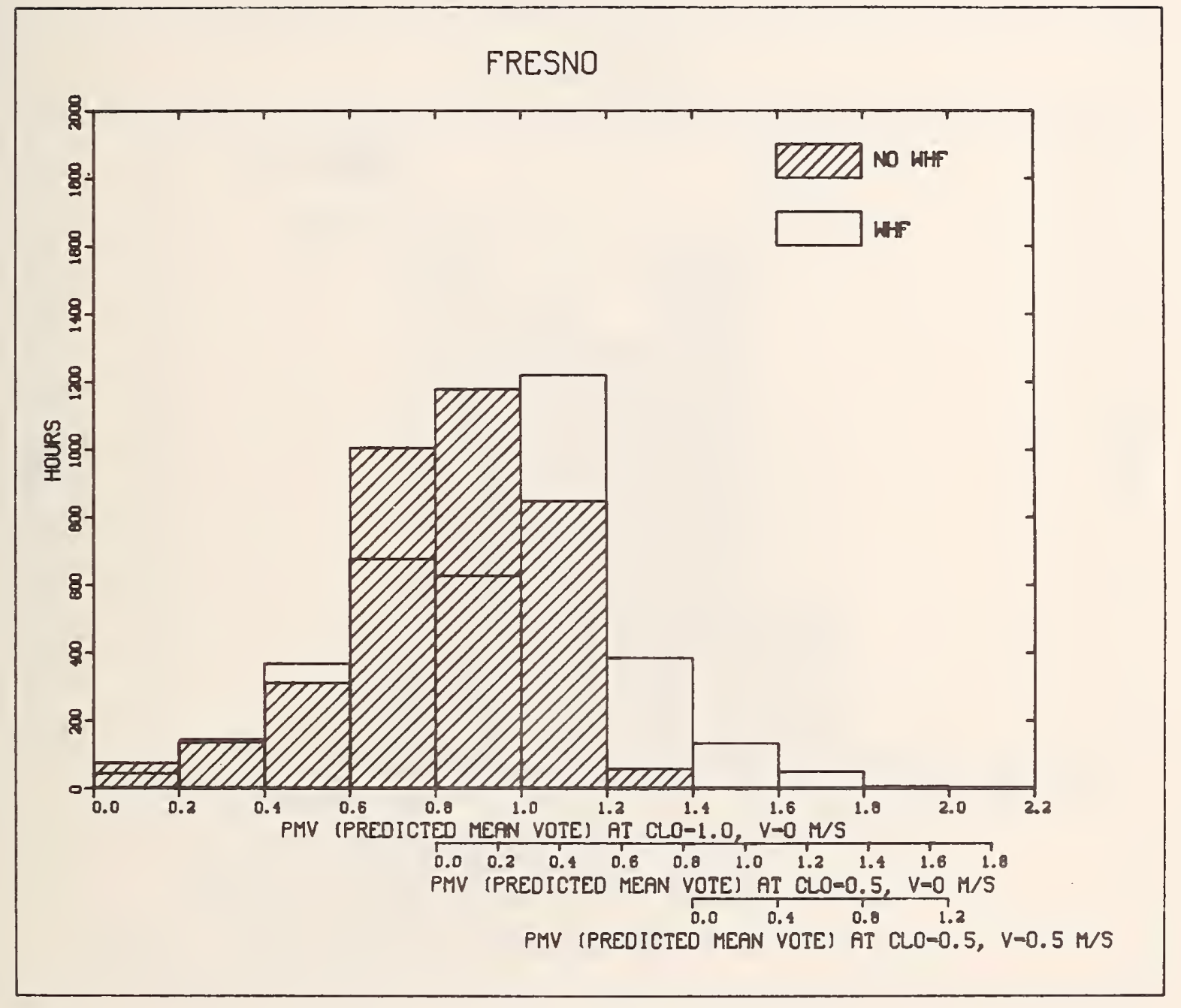

Figure 16. Predicted hourly frequency of comfort index in a typical ranch house in Fresno, CA with and without the use of whole-house fan (WHF).

PMV $=$ Fanger's Predicted Mean Vote

PMV=0 comfortable; PMV=1 slightly warm; PMV=2 warm. 


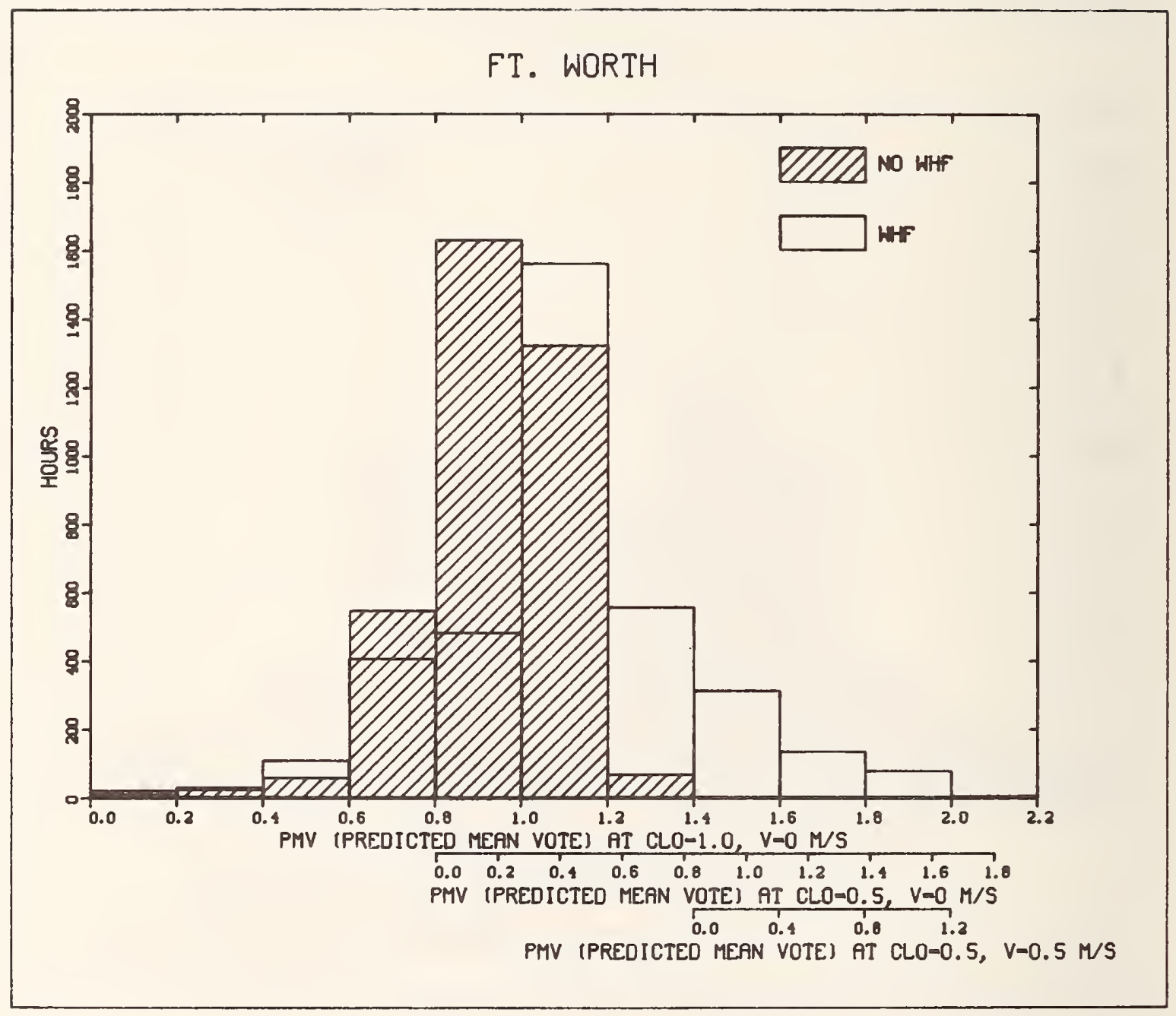

Figure 17. Predicted hourly frequency of comfort index in a typical ranch house in Ft. Worth, TX with and without the use of whole-house fan (WHF).

PMV $=$ Fanger's Predicted Mean Vote

PMV=0 comfortable; PMV=1 slightly warm; PMV=2 warm. 


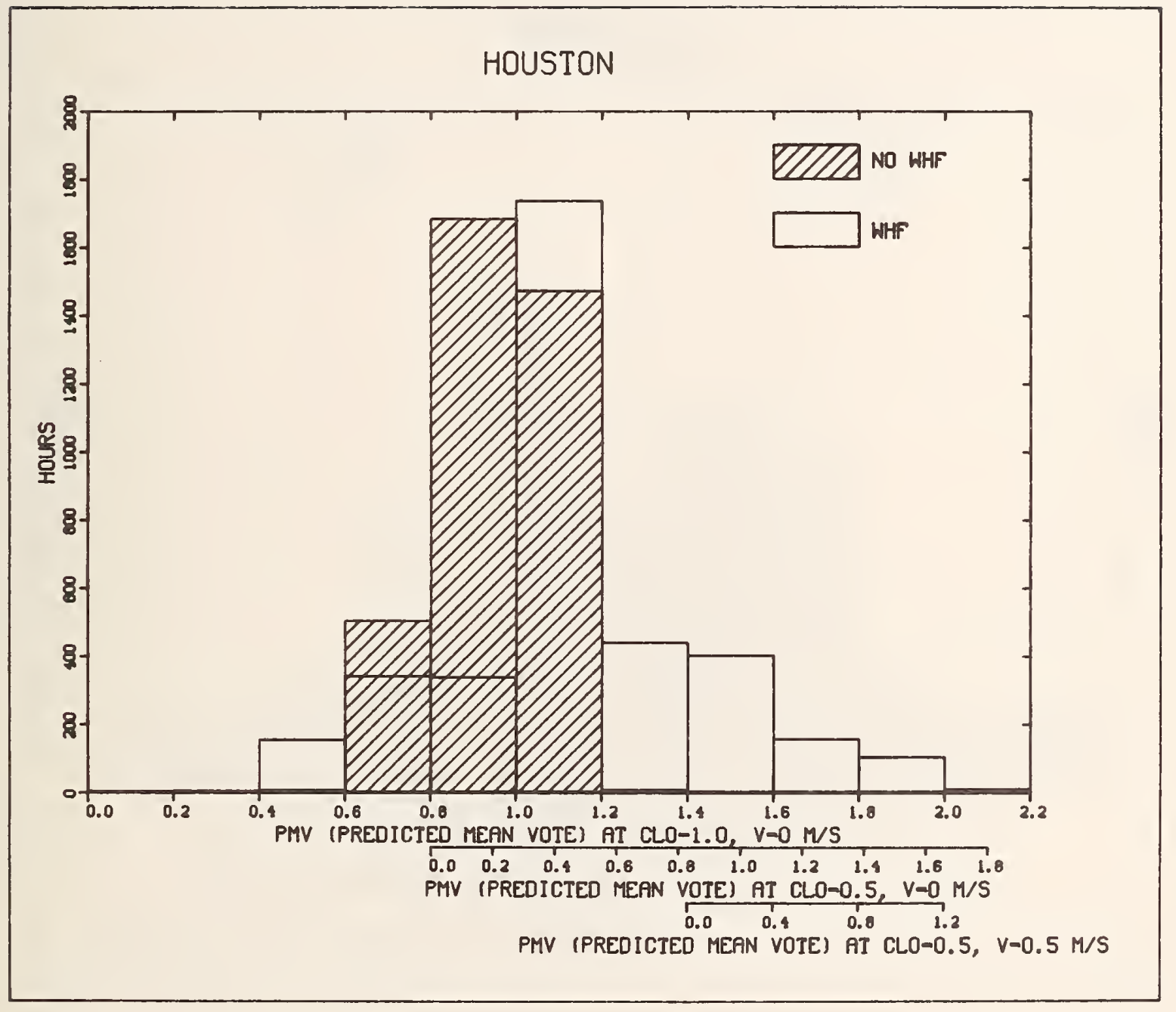

Figure 18. Predicted hourly frequency of comfort index in a typical ranch house in Houston, TX with and without the use of whole-house fan (WHF).

PMV =Fanger's Predicted Mean Vote

$P M V=0$ comfortable; $P M V=1$ slightly warm; $P M V=2$ warm. 


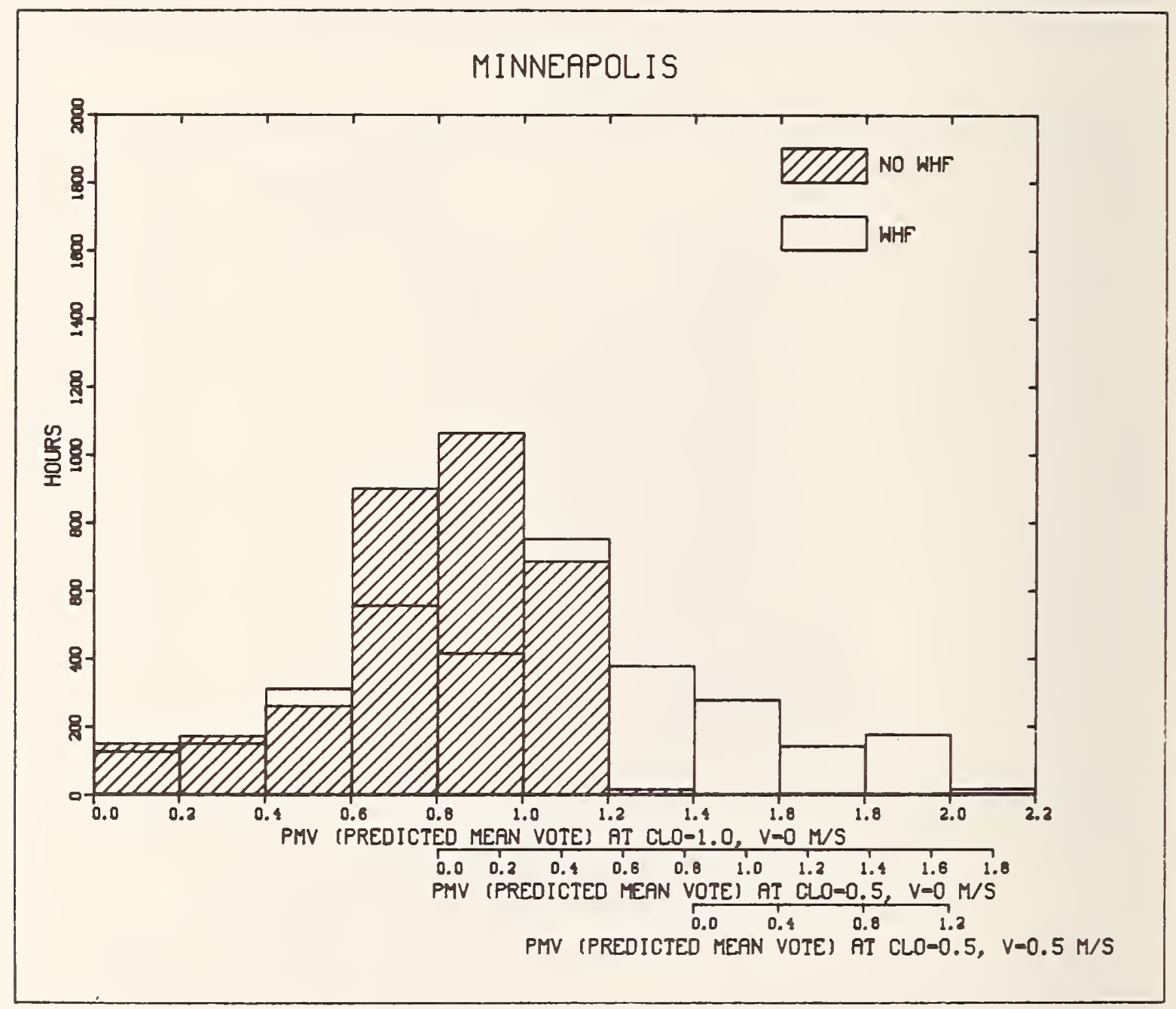

Figure 19. Predicted hourly frequency of comfort index in a typical ranch house in Minneapolis, MN with and without the use of whole-house fan (WHF).

PMV=Fanger's Predicted $M$ ean Vote PMV=0 comfortable; PNV=1 slightly warm; $P M V=2$ warm. 


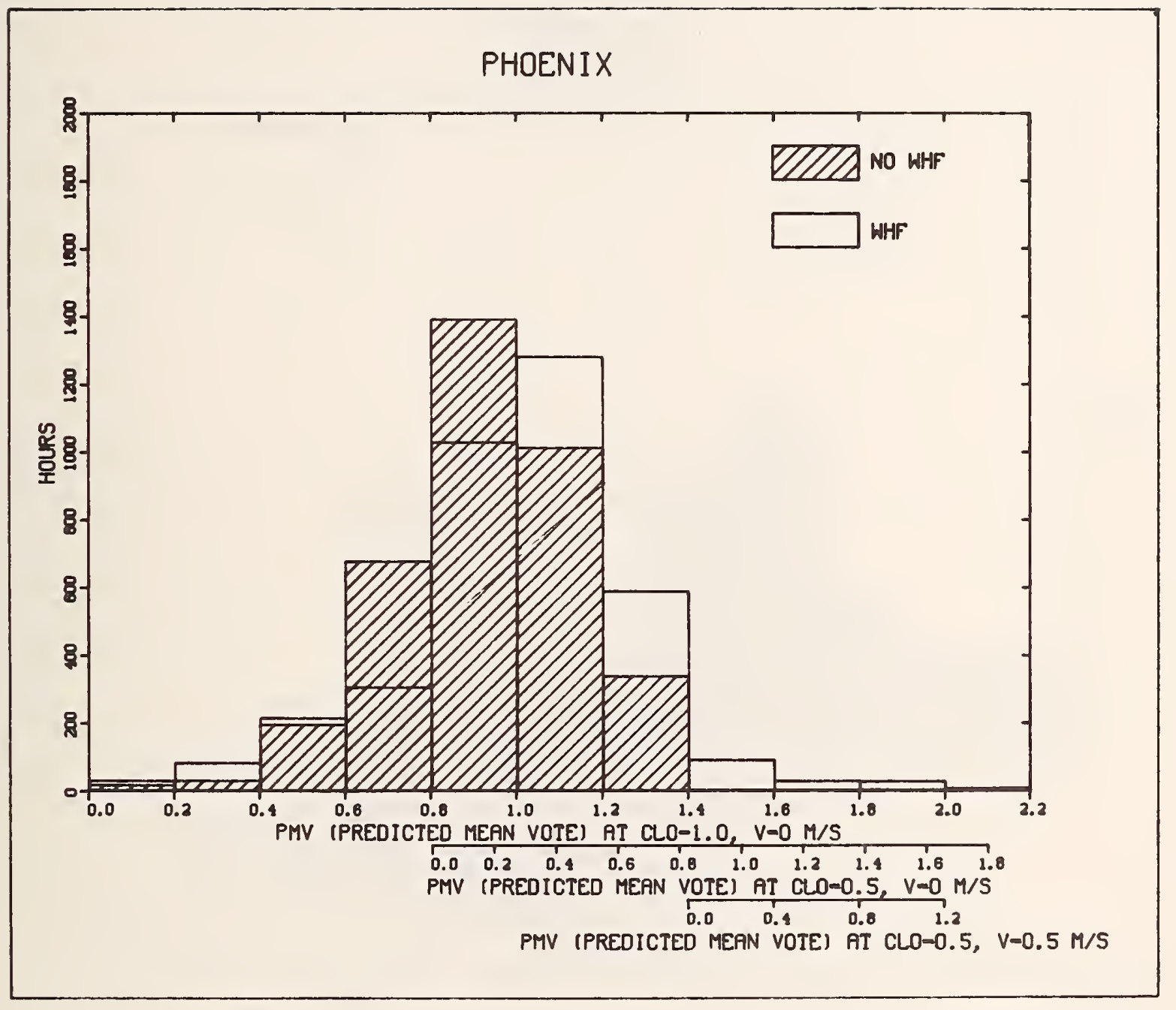

Figure 20. Predicted hourly frequency of comfort index in a typical ranch house in Phoenix, AZ with and without the use of whole-house fan (WHF).

PMV=Fanger's Predicted Mean Vote

$P M V=0$ comfortable; $P M V=1$ slightly warm; PMV=2 warm. 


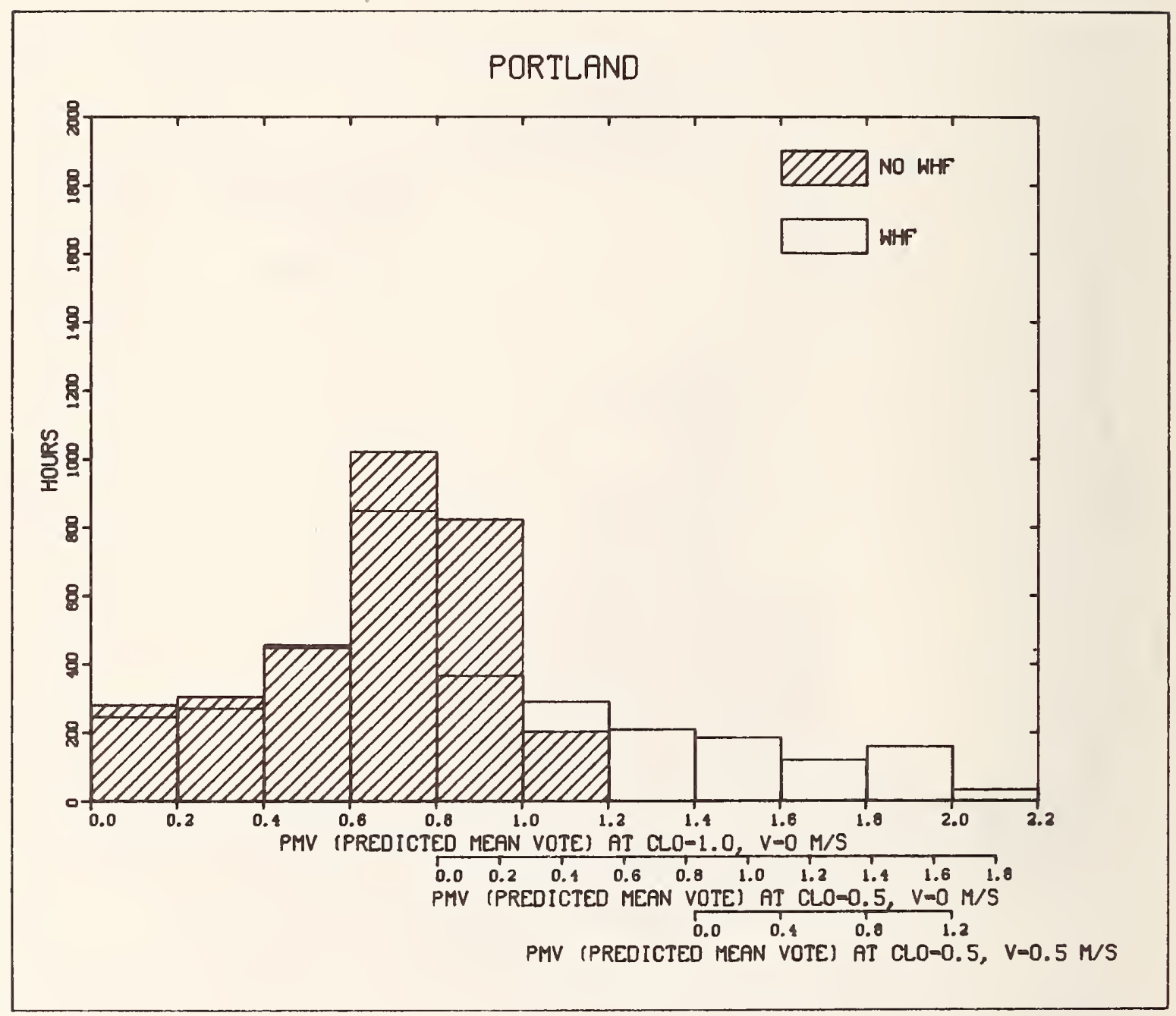

Figure 21. Predicted hourly frequency of comfort index in a typical ranch house in Portland, OR with and without the use of whole-house fan (WHF).

PMV =Fanger's Predicted Mean Vote

PMV=0 comfortable; PMV=1 slightly warm; PMV=2 warm. 


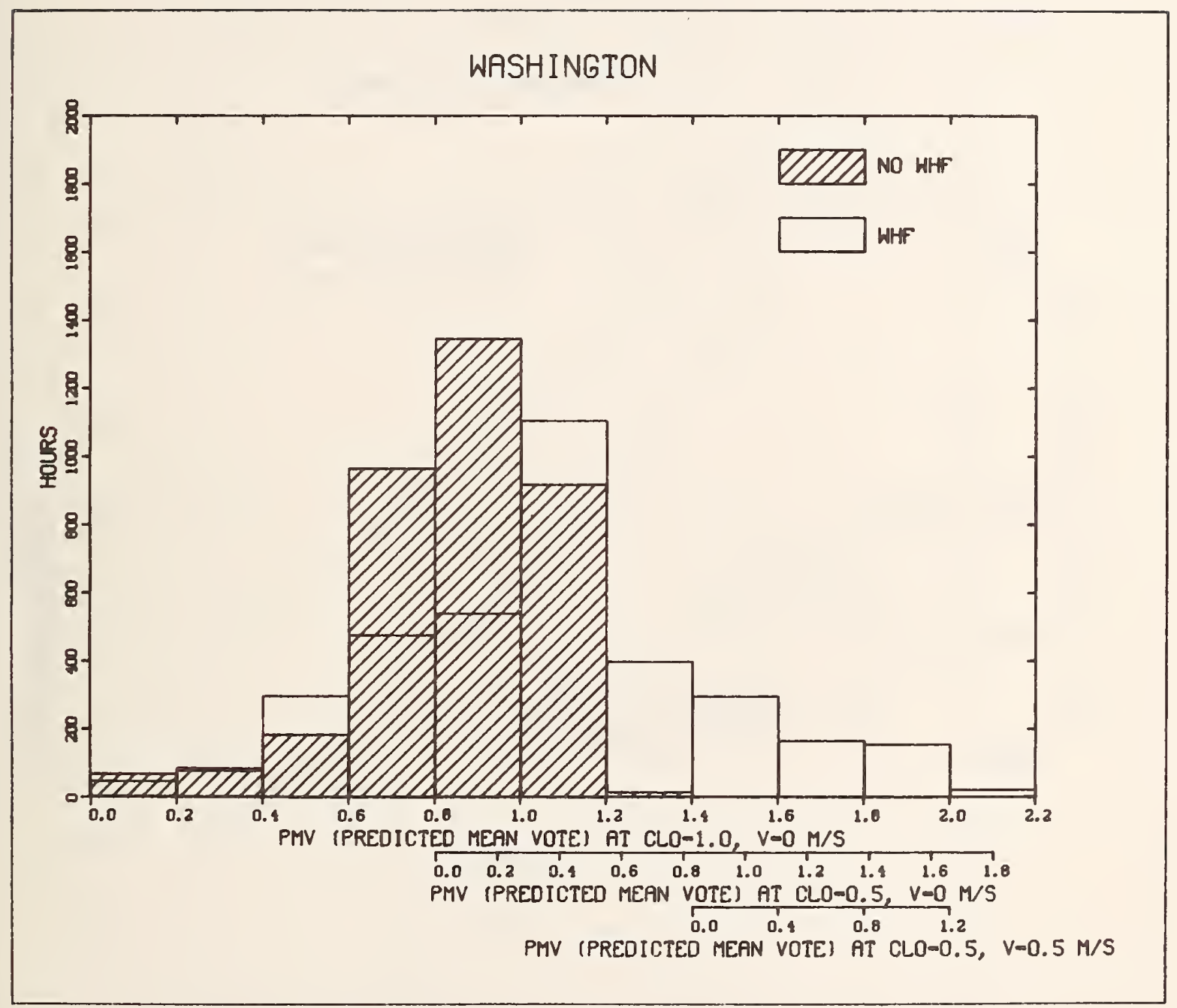

Figure 22. Predicted hourly frequency of comfort index in a typical ranch house in Washington, DC with and without the use of whole-house fan (WHF).

$P M V=F a n g e r ' s$ Predicted Mean Vote

$\mathrm{PMV}=0$ comfortable; $\mathrm{PMV}=1$ slightly warm; $\mathrm{PMV}=2$ warm. 


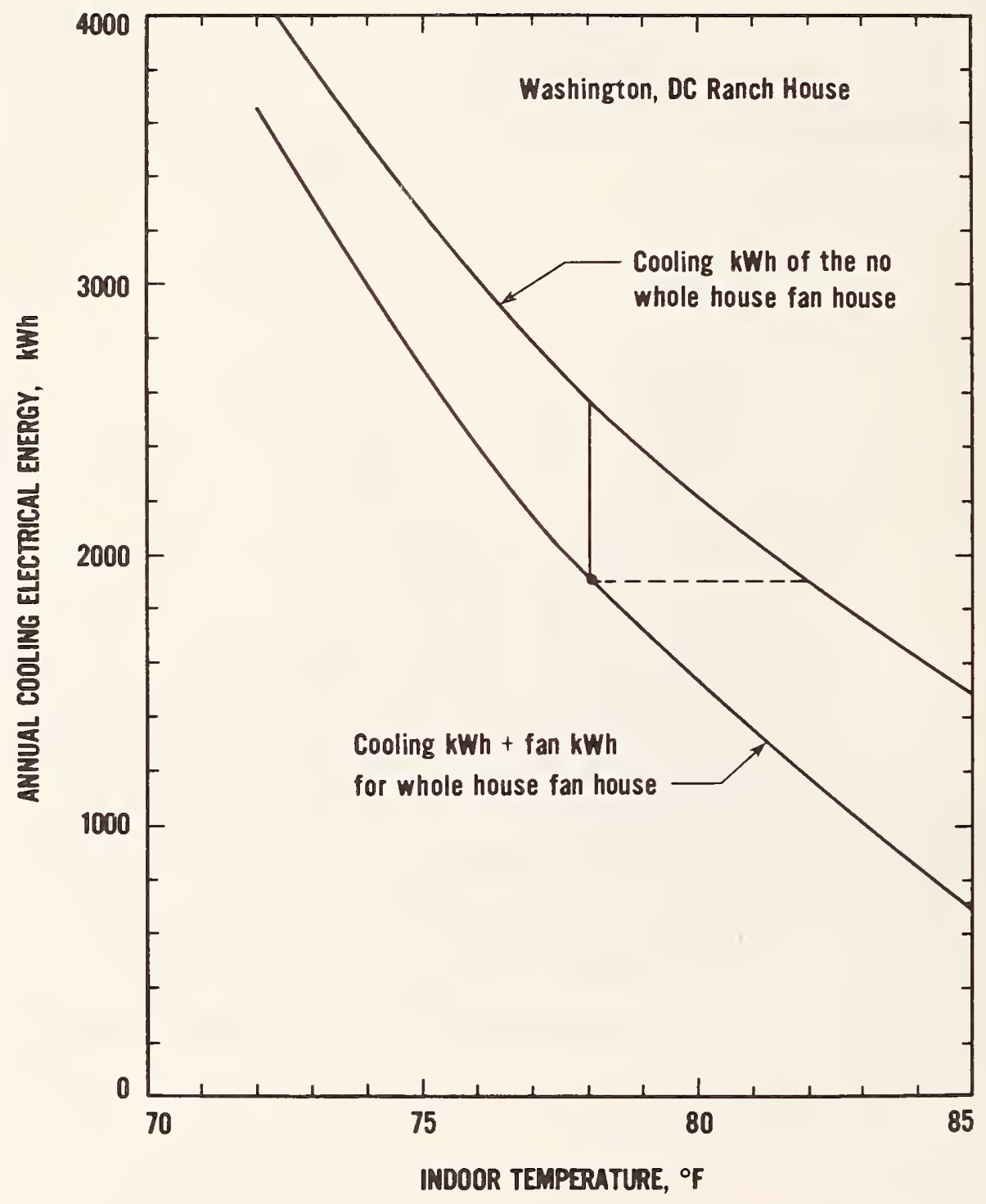

Figure 23. Annual cooling kWh vs indoor thermostat settings in a Washington D.C. ranch house. 


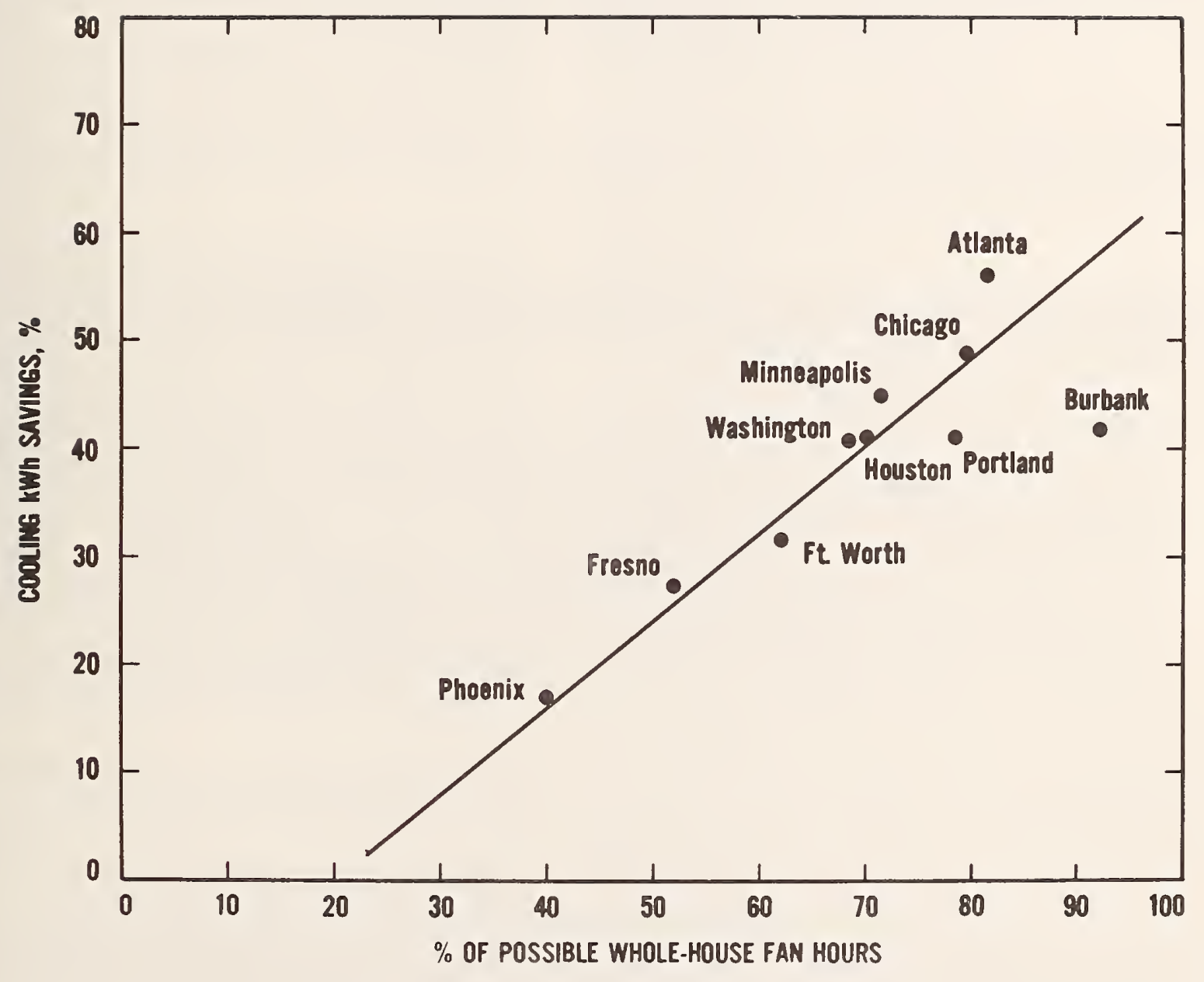

Figure 24. Cooling kWh savings vs percent of possible whole-house fan hours. 
NBS.114A (REV. 2-8C)

U.S. DEPT. OF COMM.

BIBLIOGRAPHIC DATA

SHEET (See instructions)

4. TITLE AND SUBTITLE 1. PUBLICATION OR
REPORT NO.

NBS TN 1138
2. Performing Organ. Report No.

3. Publication Date

May 1981

Savings in Electric Cooling Energy by the Use of a Whole-House Fan

5. $\operatorname{AUTHOR}(S)$

T. Kusuda and J.W. Bean

6. PERFORMING ORGANIZATION (If joint or other than NBS, see instructions)

7. Contract/Grant No.

NATIONAL BUREAU OF STANDARDS

DEPARTMENT OF COMMERCE

WASHINGTON, D.C. 20234

8. Type of Report \& Period Covered

Final

9. SPONSORING ORGANIZATION NAME AND COMPLETE ADDRESS (Street, City. State, ZIP)

Same as above.

10. SUPPLEMENTARY NOTES

Document describes a computer program; SF-185. FIPS Software Summary, is attached.

11. ABSTRACT (A 200-word or less factual summary of most significant information. If document includes a significant

bibliography or literature survey, mention it here

Hour-by-hour cooling performances of a typical ranch house, with and without the use of a whole-house fan, were compared for the climate conditions throughout the contiguous United States. The comparative analyses were made by the use of NBSWHF, a modified version of NBSLD, to simulate the complex thermal coupling of whole-house-fan ventilated attic space. The calculations were performed for two operational modes: a cyclic fan mode and a stepwise continuous mode. The calculation predicted a large cooling energy savings as compared to the house without the use of the whole-house fan, without significant deterioration of indoor thermal comfort.

12. KEY WORDS (Six to twelve entries; alphabetical order; capitalize only proper names; and separate key words by semicolons) building thermal performance; energy calculation; energy conservation; thermal comfort; whole-house ventilation

\section{AVAILABILITY}

X] Unlimited

For Official Distribution. Do Not Release to NTIS

x Order From Superintendent of Documents, U.S. Government Printing Office, Washington, D.C. 20402.

Order From National Technical Information Service (NTIS), Springfield, VA. 2216 I
14. NO. OF PRINTED PAGES 39

15. Price

$\$ 2.75$ 


\section{NBS TECHNICAL PUBLICATIONS}

\section{PERIODICALS}

JOURNAL OF RESEARCH-The Journal of Research of the National Bureau of Standards reports NBS research and development in those disciplines of the physical and engineering sciences in which the Bureau is active. These include physics, chemistry, engineering, mathematics, and computer sciences. Papers cover a broad range of subjects, with major emphasis on measurement methodology and the basic technology underlying standardization. Also included from time to time are survey articles on topics closely related to the Bureau's technical and scientific programs. As a special service to subscribers each issue contains complete citations to all recent Bureau publications in both NBS and nonNBS media. Issued six times a year. Annual subscription: domestic \$13; foreign $\$ 16.25$. Single copy, \$3 domestic; \$3.75 foreign.

NOTE: The Journal was formerly published in two sections: Section A "Physics and Chemistry" and Section B "Mathematical Sciences."

DIMENSIONS/NBS-This monthly magazine is published to inform scientists, engineers, business and industry leaders, teachers, students, and consumers of the latest advances in science and technology, with primary emphasis on work at NBS. The magazine highlights and reviews such issues as energy research, fire protection, building technology, metric conversion, pollution abatement, health and safety, and consumer product performance. In addition, it reports the results of Bureau programs in measurement standarós and techniques, properties of matter and materials, engineering standards and services, instrumentation, and automatic data processing. Annual subscription: domestic \$11; foreign $\$ 13.75$.

\section{NONPERIODICALS}

Monographs-Major contributions to the technical literature on various subjects related to the Bureau's scientific and technical activities.

Handbooks-Recommended codes of engineering and industrial practice (including safety codes) developed in cosperation with interested industries, professional organizations, and regulatory bodies.

Special Publications-Include proceedings of conferences sponsored by NBS, NBS annual reports, and other special publications appropriate to this grouping such as wall charts, pocket cards, and bibliographies.

Applied Mathematics Series-Mathematical tables, manuals, and studies of special interest to physicists, engineers, chemists, biologists, mathematicians, computer programmers, and others engaged in scientific and technical work.

National Standard Reference Data Series-Provides quantitative data on the physical and chemical properties of materials, compiled from the world's literature and critically evaluated. Developed under a worldwide program coordinated by NBS under the authority of the National Standard Data Act (Public Law 90-396).
NOTE: The principal publication outlet for the foregoing data is the Journal of Physical and Chemical Reference Data (JPCRD) published quarterly for NBS by the American Chemical Society (ACS) and the American lnstitute of Physics (AIP). Subscriptions, reprints, and supplements available from ACS, 1155 Sixteenth St., NW, Washington, DC 20056.

Building Science Series-Disseminates technical information developed at the Bureau on building materials, components, systems, and whole structures. The series presents research results, test methods, and performance criteria related to the structural and environmental functions and the durability and safety characteristics of building elements and systems.

Technical Notes-Studies or reports which are complete in themselves but restrictive in their treatment of a subject. Analogous to monographs but not so comprehensive in scope or definitive in treatment of the subject area. Often serve as a vehicle for final reports of work performed at NBS under the sponsorship of other government agencies.

Voluntary Product Standards-Developed under procedures published by the Department of Commerce in Part 10, Title 15, of the Code of Federal Regulations. The standards establish nationally recognized requirements for products, and provide all concerned interests with a basis for common understanding of the characteristics of the products. NBS administers this program as a supplement to the activities of the private sector standardizing organizations.

Consumer Information Series-Practical information, based on NBS research and experience, covering areas of interest to the consumer. Easily understandable language and illustrations provide useful background knowledge for shopping in today's technological marketplace.

Order the above NBS publications from: Superintendent of Documents, Government Printing Office, Washington, DC 20402.

Order the following NBS publications-FIPS and NBSIR's-from the National Technical Information Services, Springfield, VA 22161.

Federal Information Processing Standards Publications (FIPS PUB)-Publications in this series collectively constitute the Federal Information Processing Standards Register. The Register serves as the official source of information in the Federal Government regarding standards issued by NBS pursuant to the Federal Property and Administrative Services Act of 1949 as amended, Public Law 89-306 (79 Stat. 1127), and as implemented by Executive Order 11717 (38 FR 12315, dated May 11, 1973) and Part 6 of Title 15 CFR (Code of Federal Regulations).

NBS Interagency Reports (NBSIR)-A special series of interim or final reports on work performed by NBS for outside sponsors (both government and non-government). In general, initial distribution is handled by the sponsor; public distribution is by the National Technical Information Services, Springfield, VA 22161, in paper copy or microfiche form. 
U.S. DEPARTMENT OF COMMERCE

National Bureau of Standards

Washington, D.C. 20234

OFFICIAL BUSINESS

Penalty for Private Use, $\mathbf{\$ 3 0 0}$ 